EarthArXiv preprint which has been peer-reviewed and revised once in Journal of Volcanology and Geothermal Research and will shortly be transferred to another journal.

\author{
Manuscript R1 submitted to Journal of Volcanology and Geothermal Research \\ June 2020
}
PREPRINT: a doi will be provided in due course to the final peer-reviewed article in a different journal.

Comments are welcome by contacting the corresponding author directly.

\title{
Pleistocene - Holocene volcanism at the Karkar geothermal prospect, Armenia
}

\author{
Khachatur Meliksetian' ${ }^{1}$ Iain Neill2*, Dan N. Barfod ${ }^{3}$, Eilidh J.M. Milne ${ }^{2}$, Emma C. Waters ${ }^{4}$, Gevorg \\ Navasardyan $^{1}$, Edmond Grigoryan $^{1}$, Valerie Olive $^{5}$, Nicholas Odling ${ }^{6}$, Arkady Karakhanian ${ }^{1 \dagger}$ \\ ${ }^{1}$ Institute of Geological Sciences, National Academy of Sciences, 24a Marshal Baghramyan Avenue, 0019, \\ Yerevan, Armenia. \\ ${ }^{2}$ School of Geographical and Earth Sciences, University of Glasgow, Gregory Building, Lilybank Gardens, \\ Glasgow, G12 8QQ, Scotland. \\ ${ }^{3}$ NEIF Argon Isotope Facility, Scottish Universities Environmental Research Centre, Rankine Avenue, Scottish \\ Enterprise Technology Park, East Kilbride, G75 OQF, Scotland. \\ ${ }^{4}$ Department of Earth and Environmental Sciences, University of Manchester, Williamson Building, Oxford Road, \\ Manchester, M13 9PL, England. \\ ${ }^{5}$ Scottish Universities Environmental Research Centre, Rankine Avenue, Scottish Enterprise Technology Park, East \\ Kilbride, G75 0QF, UK. \\ ${ }^{6}$ School of GeoSciences, Grant Institute, University of Edinburgh, Kings Buildings, James Hutton Road, \\ Edinburgh, EH9 3FE, Scotland. \\ ${ }^{\dagger}$ Deceased. \\ ${ }^{*}$ Corresponding author. E-mail: iain.neill@glasgow.ac.uk; Phone: +44 1413305477.
}

\begin{abstract}
Quaternary volcanic centres north of the Bitlis-Zagros suture in Turkey, Iran and the Caucasus represent both volcanic hazards and potential or actual geothermal energy resources. Such challenges and opportunities cannot be fully quantified without understanding these volcanoes' petrogenesis, geochronology and magmatic, tectonic or other eruption triggers. In this preliminary study, we discuss the age and geology of the Karkar monogenetic volcanic field in Syunik, SE Armenia. The $70 \mathrm{~km}^{2}$ field is close to Armenia's only geothermal energy test drilling site. Fissurefed trachybasaltic andesite to trachyandesite lavas erupted on a trans-tensional segment of the Syunik branch of the Pambak-Sevan-Syunik Fault, where previous studies suggested a Holocene age for the youngest eruptions. Here, high-resolution duplicate ${ }^{40} \mathrm{Ar} /{ }^{39} \mathrm{Ar}$ dating of 7 groundmass separates provided composite plateau or inverse isochron ages ranging from $6 \pm 3 \mathrm{ka}$ and $8 \pm 3 \mathrm{ka}$ to $332 \pm 9 \mathrm{ka}(2 \sigma)$. Each lava flow displays petrographic and whole rock geochemical patterns consistent with melting of subduction-modified lithospheric mantle and extensive evolution within the crust involving fractional crystallisation and mixing of magma batches. Data confirm that volcanic activity in Syunik and also Vardenis provinces overlapped with Palaeolithic to Bronze Age human occupation and remains a minor lava inundation hazard. Further geochemical work will allow constraint of the depth and timescales of magma storage. Both Karkar and the area around Porak volcano, which lies $35 \mathrm{~km} N$ of Karkar on the Syunik Fault, might be considered for future geothermal energy developments.
\end{abstract}

\section{Keywords}

Armenia; ${ }^{40} \mathrm{Ar} /{ }^{39} \mathrm{Ar}$ geochronology; Geochemistry; Geothermal Energy; Monogenetic Volcanism; Hazards

\section{Highlights}

- Monogenetic volcanism close to new geothermal energy development in SE Armenian Uplands

- Last eruptions during the Holocene based on ${ }^{40} \mathrm{Ar} /{ }^{39} \mathrm{Ar}$ geochronology and archaeology

- Magmas sourced from sub-continental mantle lithosphere followed by fractionation and mixing 
- Further identification of magma storage conditions will assist geothermal development

- Volcanism still poses a hazard in this area and geophysical monitoring is recommended

\section{Introduction}

This paper presents new ${ }^{40} \mathrm{Ar} /{ }^{39} \mathrm{Ar}$ dating evidence that volcanism in Armenia has occurred during the Holocene. Taking the country's first geothermal energy test site as a case study, we discuss the origin of this volcanism. The work serves as notice that deeper investigation into the geochronology of volcanic activity, the depth and timescales of magma storage, and the potential for further geothermal energy development, should be future lines of research in the country.

Armenia (pop. 3.0 million) is a landlocked nation in the South Caucasus (Fig. 1). As a former Soviet state, with difficult political relations with neighbours Turkey and Azerbaijan, and closed borders to those countries, Armenia's energy needs are heavily dependent on Russian and Iranian hydrocarbon supplies and on the Metsamor nuclear facility located $30 \mathrm{~km}$ west of the capital city, Yerevan. Recently, the Armenian government have increased investment in renewable energy prospects, including hydropower, wind, solar and geothermal energy. In 20082015 the World Bank supported detailed geological, geophysical investigations within the Karkar plateau followed by drilling of two test wells that began in 2016 at the Karkar geothermal site. The site lies in Syunik Province in the remote SE of the country (Fig. 1). The Karkar site was recognised as promising based on earlier studies from a well drilled in 1988 (Fig. 2; Gilliland et al., 2018; Georisk, 2012; White et al., 2015). The site is on a plateau around 3,000 m a.s.l., formed largely from Mesozoic-Cenozoic ophiolitic materials and Cenozoic lava flows and intrusions, cut by the Syunik branch of the Pambak-Sevan-Syunik (PSSF) fault system (Karakhanian et al., 1997; Meliksetian, 2013), hereafter the Syunik Fault.

Armenia has an extensive history of Late Cenozoic volcanism, related to the Arabia-Eurasia collision. However, compared to other active or potentially active volcanic areas globally, few modern and precise petrogenetic studies have been carried out (Neill et al., 2013, 2015; Sugden et al., 2019). K/Ar dates and major element analyses have been produced for Armenian rocks via the Russian Academic of Sciences (e.g. Arutunyan et al., 2007; Chernyshev et al., 2006; Lebedev et al., 2010), and ${ }^{40} \mathrm{Ar} /{ }^{39} \mathrm{Ar}$ dates exist for the Pleistocene Javakheti-Samsari Ridge in N Armenia and S Georgia (Nomade et al., 2016). However, there has been little focus on the very youngest magmatism, especially in the south of Armenia. There are some permanent and temporary GPS and seismic monitoring stations, run by the Institute of Geological Sciences of the National Academy of Sciences of Armenia, which may help monitor the movement of magma at depth within the crust (Karakhanyan et al., 2017; Sargsyan et al., 2017). However, just two seismic installations are reasonably near, at 25 and $50 \mathrm{~km}$, to the aforementioned Karkar site. Several volcanic uplands in Armenia are argued to have experienced Holocene eruptions, but most records depend on interpretations of ancient manuscripts, inscriptions and petroglyphs, ${ }^{14} \mathrm{C}$ dating of archaeological sites and on post-glacial geomorphology (Karakhanian et al., 2002). To our knowledge none of the youngest, potentially Holocene, volcanic centres have peer-reviewed data for the depth of magma storage, their eruption triggers or radiometric determinations of their precise age, though a range of non-reviewed or locally-published radiometric and cosmogenic dates are emerging (see sections 2.2 and 6.1). There is an urgent need to fill this knowledge gap around very recent volcanic activity, considering both volcanic hazards and the country's potential future energy investments. This paper's primary objective is to document the age and origin of the youngest magmatism in the Karkar monogenetic volcanic field, given its importance as Armenia's first geothermal test drilling site. We will: (1) use high-resolution ${ }^{40} \mathrm{Ar} /{ }^{39} \mathrm{Ar}$ dating to further assess evidence for Holocene volcanic activity at Karkar; (2) use petrography and geochemistry to provide a preliminary account of the petrogenesis of the erupted lavas, and compare them to other recent magmatism across Armenia; and (3) provide a description of the future research steps which might be important to undertake in the area in terms of its geothermal energy potential and volcanic hazards. 

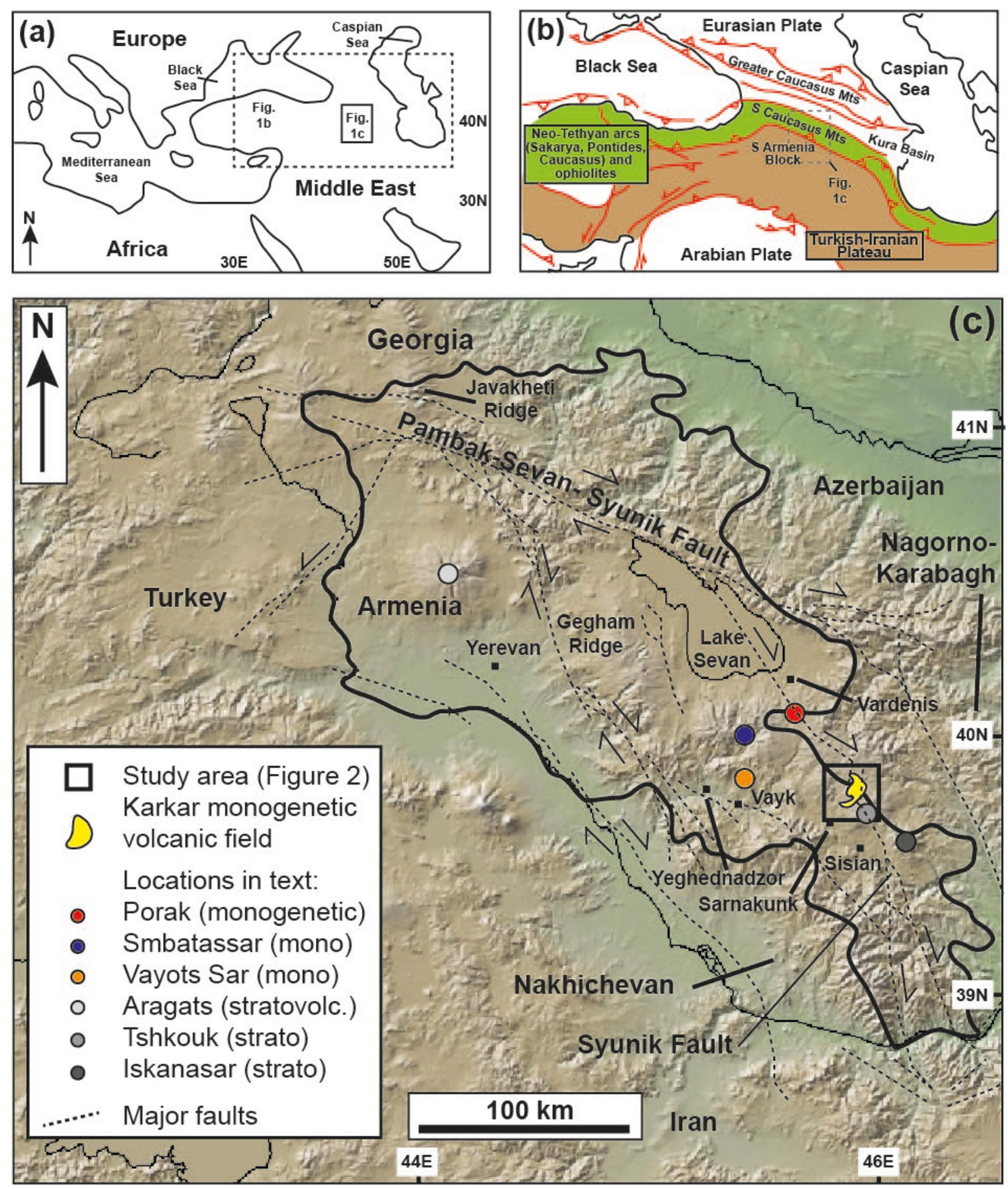

Figure 1. a) Regional setting of the study. b) Main crustal blocks discussed in the text. c) A map of Armenia in the South Caucasus showing the locations of major volcanoes or volcanic fields, faults, and towns mentioned in this text. Background relief map extracted from GeoMapApp v3.6.10 (http://geomapapp.org; Ryan et al. 2009). Relative fault motions from Karakhanyan et al. (2017).

\section{Geological Background}

2.1. The Arabia-Eurasia collision zone and Armenia

Armenia is part of the Arabia-Eurasia collision zone, itself belonging to the Alpine-Himalayan orogenic belt resulting from the closure of the Tethys Ocean during the Late Mesozoic - Cenozoic. The country is landlocked in the South Caucasus mountains (Fig. 1) and consists of two crustal domains. To the N and NE are assemblages of 
subduction-related igneous rocks formed during closure of the northern branch of the Neo-Tethys Ocean during the Mesozoic (Galoyan, et al., 2007, Mederer et al., 2013; Rolland et al., 2017). In the S is the South Armenian Block (SAB), which is poorly exposed beneath Cenozoic volcanic and sedimentary rocks. The SAB is considered to represent a microcontinental fragment of Proterozoic to Palaeozoic age that detached from Gondwanaland during the formation of Neo-Tethys (Sosson et al., 2010). Between these two domains is a structurally complex zone of ophiolitic fragments of mostly Jurassic to Cretaceous age (Galoyan et al., 2007, Sosson et al., 2010). Eocene intrusive rocks across much of Armenia may be a product of back-arc extension during subduction of the southern branch of Neo-Tethys beneath Turkey and Iran (Sahakyan et al. 2016). Armenia has experienced late Cenozoic transpressional tectonics due to the ongoing Arabia-Eurasia collision and is today crossed by the right-lateral Pambak-Sevan-Syunik Fault (PSSF), which cuts through Lake Sevan and has several branches extending for $\sim 400$ kilometres NW-SE and N-S through the country, exploiting the older suture (Fig. 1c). There is modern, historical and archaeological historical evidence for centennial-millennial earthquakes $\geq \mathrm{M}_{\mathrm{w}} 7.0$, including the 1988 Spitak quake that killed over 25,000 people (Karakhanian et al., 2004). Extensive Late Cenozoic collisional magmatism is spatially related to zones of extension triggered by fault curvature, local pull-apart structures or interactions between several fault systems (see discussions in Karakhanian et al., 2002; 2016; Neill et al., 2013).

Recent geochemical analyses demonstrate that Late Cenozoic magmatism has a subduction-modified subcontinental lithospheric mantle source (Sugden et al., 2019). Magmatism largely post-dates break-off of one or more Neo-Tethyan slabs and therefore is likely to be driven by combinations of long-lived mantle upwelling due to break-off, sub-lithospheric convection and lithospheric thinning, and petrological triggers such lithospheric mantle P/T conditions intersecting the amphibole peridotite solidus (Neill et al., 2015; Sugden et al., 2019).

\subsection{Current evidence for Holocene volcanism in Armenia}

One of the broad questions associated with Late Cenozoic magmatism in Armenia is whether there is potential for future eruptive activity. There are hundreds of Quaternary vents and fissures built up into ridges and plateaux related to faults across Armenia. These include the Javakheti Ridge which extends into Georgia, related to extensional tectonics north of the PSSF (Neill et al., 2013); the Gegham Ridge in Gegharkunik Province which directly overlies the Garni Fault; (Karakhanian et al., 2002); and Porak volcano and the Karkar monogenetic volcanic field in Syunik Province in the SE. The last two of these lies along the Syunik branch of the PSSF that extends directly N-S from Lake Sevan (Karakhanian et al., 1997; 2002). Stratovolcanoes and related monogenetic cones have also been constructed during the Late Cenozoic, including Aragats (Armenia's highest peak at $4090 \mathrm{~m}$ ), Arailer just to the east of Aragats, and Tskhouk and Ishkanasar just south of Karkar (Gevorgyan et al., 2018; Meliksetian, 2013). There are also some isolated monogenetic centres such as Vayots Sar and Smbatassar which may be spatially related to unmapped faults (Fig. 1c).

An estimate of future potential for volcanic activity is far from complete, largely because published peer-reviewed radiometric dating of latest Pleistocene-Holocene volcanism is lacking. A range of methods have been used to determine if such young activity has occurred. Firstly, two volcanic cones south of Karkar in Syunik Province provided near-zero ${ }^{40} \mathrm{Ar} /{ }^{30} \mathrm{Ar}$ ages which might be interpreted as Holocene (Ollivier et al., 2010). A further geomorphologically very fresh cone suspected to be of Holocene age, Smbatassar, $55 \mathrm{~km}$ west of Karkar, did not produce detectable radiogenic $\mathrm{Ar}$ and is therefore proposed to be Holocene (Koppers and Miggins personal communication 2018; Karakhanian et al., 2002). Aside from the new ${ }^{40} \mathrm{Ar} /{ }^{39} \mathrm{Ar}$ data reported here there is an ${ }^{40} \mathrm{Ar} /{ }^{39} \mathrm{Ar}$ date of $3.7 \pm 4.2 \mathrm{ka}(2 \sigma)$, yet to be peer-reviewed, from a flow at the Porak volcano some $40 \mathrm{~km}$ north of Karkar on the Syunik Fault (Meliksetian et al., 2018; Figure 1c). Otherwise, archaeological and geomorphological evidence has been used several times to argue for Holocene volcanic activity by Karakhanian et al. $(1997 ; 2002)$ and Karakhanian and Abgaryan (2004). They document at least two eruptions at Porak and two or more at Karkar during the Holocene, with evidence including: (1) fresh volcanic cones and flows which have no evidence of glacial erosion; (2) manuscript records, cuneiform inscriptions and rock carvings which have been interpreted to depict volcanic activity, often coinciding with strong earthquakes and periods of conflict or social upheaval and (3) ${ }^{14} \mathrm{C}$ dating of archaeological sites where dated, artefact-bearing soils are said to be overlain by lava flows. Finally, some permanent and temporary passive seismic stations near Gegham Ridge (Fig. 1) have begun picking seismic swarms of volcano-tectonic origin, consistent with an active magma chamber at $\sim 20 \mathrm{~km}$ depth (Sargsyan et al., 2017). Collectively, these pieces of evidence mean that there is a need for corroboration of Holocene volcanic activity, both from a volcanic hazard perspective, and in preparation for sustainable exploitation of geothermal sources, especially given high heat flow and magmatic fluid sources reported from thermal springs across Armenia (Meliksetian et al., 2017). 
2.3. Introduction to the Karkar monogenetic field and recent work at the geothermal site

Porak and Karkar both lie on the Syunik Fault in S Armenia (Fig. 1c), Porak in Vardenis and Karkar in Syunik Province. The Karkar monogenetic volcanic field begins immediately south of the location of new boreholes spud in 2016, B1 and B2, for the exploration of geothermal resources (Figs 2-3; results summarised in Gilliland et al., 2018). These boreholes reached depths of approximately 1600 metres, and superseded a nearby 1988 borehole called N-4, which reached 1000 metres. None are presently in active production. 

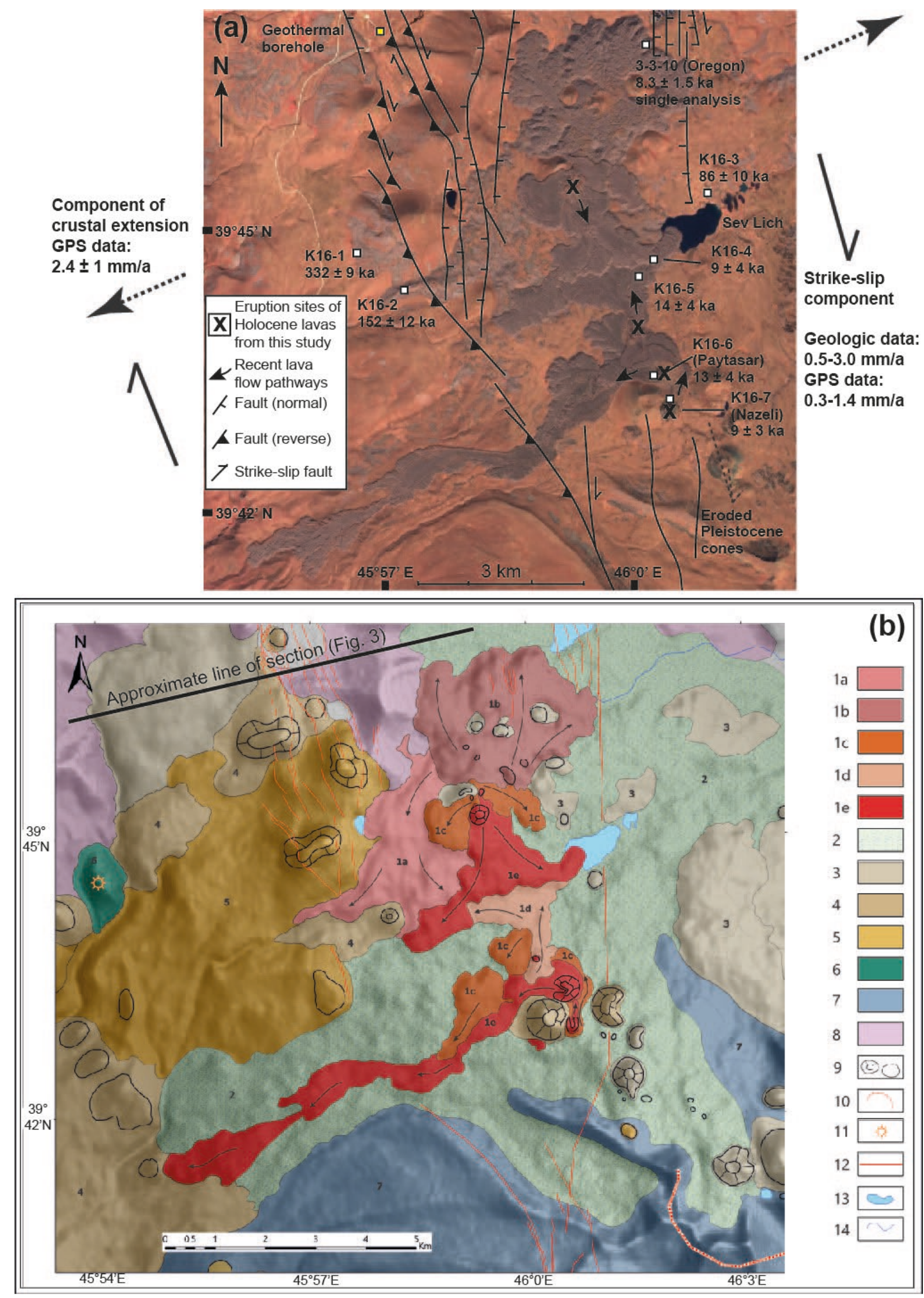

Figure 2. a) False colour image of the Karkar monogenetic field overlain with sample locations (squares), the youngest identified eruption sites $(X)$, weighted mean plateau ages and faults. Image obtained using Copernicus 
Sentinel 2 L1-C data (19-10-2018), retrieved from https://apps.sentinel-hub.com (19-2-2019), processed by the European Space Agency. Faults based on Karakhanian et al. (2002) and motion data from Karakhanyan et al. (2017). b) Geological map of the Karkar monogenetic volcanic field, as interpreted by the Institute for Geological Sciences of the National Academy of Sciences in Armenia, and the approximate location of the cross-section line for Figure 3. Key for the map units: 1: Holocene basaltic trachyandesites. $1 a=1^{\text {st }}$ generation lava flow; $1 b=2^{\text {nd }}$ generation lava flow, etc. 2: Late Pliocene to Early Pleistocene basaltic trachyandesites, trachyandesites, trachytes, trachydacites, tuffs and volcanic breccias of the Tskhouk-Ishkanasar and Goris suites. 3: Late Pleistocene glacial and fluvioglacial deposits and moraines. 4: Late Pleistocene trachybasalts, basaltic trachyandesites, trachyandesites, basanites, phonotephrites. 5: Middle Pleistocene trachybasalts, basaltic trachyandesites, basanites and phonotephrites. 7: Early Pleistocene rhyolites, obsidian domes. 9: Monogenetic volcanic centres (mostly Late Pleistocene - Holocene). 10: Crater rim of Tskhouk stratovolcano. 11: Dome-shaped rhyolitic volcanoes and related extrusive rocks. 12: Active and supposed faults. 13: Lakes. 14: Rivers. Note the discrepancy between K16-2 and K16-3 which is discussed in the text; and that units 6 and 8 are not clearly identified within the map area and therefore not listed here: these would be parts of the Tskhouk-Ishkanasar and Goris suites where the specific volcanic source can be recognised.

The youngest volcanic rocks at Karkar are fissure-fed cones and lavas that cover $\sim 70 \mathrm{~km}^{2}$ and lie northwest of two much larger polygenetic stratovolcanoes, Tskhouk and Ishkanasar, which were active during the Pleistocene (Ollivier et al., 2010; Meliksetian, 2013; Sugden et al., 2019). N-S-trending transtensional faults cut the area (Fig. 2), and ${ }^{14} \mathrm{C}$ dates from soil layers infilling fault scarps indicate fault motion has continued to the last couple of millennia (Karakhanian et al., 2002; Neill and Dunbar, unpublished data 2018). Karakhanian et al. (2002) interpreted the faults to define a pull-apart basin on a step-over between segments of the transpressive Syunik Fault (Fig. 2). The youngest lavas overlie a subdued landscape of glacially eroded, presumed Pleistocene volcanic cones and lavas, although in borehole logs there are reports of tuff and alluvium (Gilliland et al., 2018; Fig. 2b). Though the tuff is a plausible identification, given the proximity of Tskhouk and Ishkanasar stratovolcanoes, we viewed the borehole chippings in 2016 and considered much of the material as lava which had experienced extensive hydrothermal alteration, resulting in a yellow-brown, clay-rich texture with partially corroded phenocrysts. These materials reach a depth of almost $1000 \mathrm{~m}$ in both wells B1 and B2 and are cut by a body of quartz monzonite encountered in well B2 at 155-241 m depth. GeoRisk (2012) argued the monzonite was part of a series of shallow syenite domes or plugs, but they have never been precisely dated and are currently recorded as 'NeogeneQuaternary' (Fig. 3). Much of the local area is further underlain by an alkaline granitoid body or bodies collectively called the Tsarasar (Dalidagh) intrusion (GeoRisk, 2012). The Tsarasar body was presumed to have an early Miocene phase based on a K-Ar date of $22.3 \mathrm{Ma}$ (Baghdasaryan and Ghukasyan, 1985). Recently, Melkonyan et al. (2019) reported a new U-Pb date for zircons from a single syenogranite sample from the body, of $26.92 \pm 0.27 \mathrm{Ma}$ $(2 \sigma)$ (Late Oligocene). Small intrusive exposures across the wider area suggest further phases including those of speculated early Miocene, early Oligocene and possibly younger ages, but these are also largely based on petrographic comparison with other units (GeoRisk, 2012). Wells B1 and B2 record marble, greywacke, quartzite and serpentinite down to their bases, rock types confirming the country rock to be part of the suture between the $\mathrm{SAB}$ and the Eurasian margin (Sosson et al., 2010). A lack of nearby seismic stations means few recent earthquakes have been recorded near Karkar, however GPS stations do record dextral fault motion and extension on the Syunik branch of the PSSF (Karakhanian et al., 2013; Fig. 2a) raising the possibility that some deformation is taken up by aseismic slip or creep in weak lithologies such as the serpentinite.

Prior to the drilling of wells B1 and B2, detailed magneto-telluric and gravity investigation was carried out (GeoRisk, 2012; White et al., 2015). White et al. (2015) proposed that the geothermal resource was based not on the most recent volcanic materials but on the shallow quartz monzonite intrusion(s). It is vital that this body be assigned a precise absolute age in the future. However, Gilliland et al.'s (2018) updated model suggested a deeper, unknown heat source which could be a subject for future studies. White et al. (2015) concluded that the geothermal waters were largely meteoric in origin, fed through faults and eventually returned to the surface via hot springs. The 1980 's N-4 borehole cut into the uppermost parts of the Tsarasar body, encountering temperatures of nearly $100^{\circ} \mathrm{C}$ at a depth of $1 \mathrm{~km}$ (Georisk, 2012). The later B1 borehole recorded $116^{\circ} \mathrm{C}$ at $1460 \mathrm{~m}$ (Gilliland et al., 2018). A modest injectivity of $7 \mathrm{t} \mathrm{hr}^{-1} \mathrm{bar}^{-1}$ was recorded in 2016 and a fluid flow of $801 \mathrm{~min}^{-1}$. The B2 borehole recorded $124^{\circ} \mathrm{C}$ at $1600 \mathrm{~m}$, rising to $135^{\circ} \mathrm{C}$ by the end of testing, with an injectivity of $0.7 \mathrm{t} \mathrm{hr}^{-1} \mathrm{bar}^{-1}$. A noted $>250 \mathrm{~m}$ difference in static water level between the two boreholes was explained by the two boreholes being separated by one of several faults which have probably caused reservoir compartmentalisation (Gilliland et al., 2018). The final conclusions of Gilliland et al. (2018) were that the main permeable depths in the existing B1 and B2 wells were 
potentially suitable for district heating use, but that the hotter deep part of the wells passed through largely impermeable material. It was recommended the wells be extended to up to $3000 \mathrm{~m}$ depth beneath the surface for exploitation for electricity generation, where Gilliland et al. (2018) expected greater permeability.

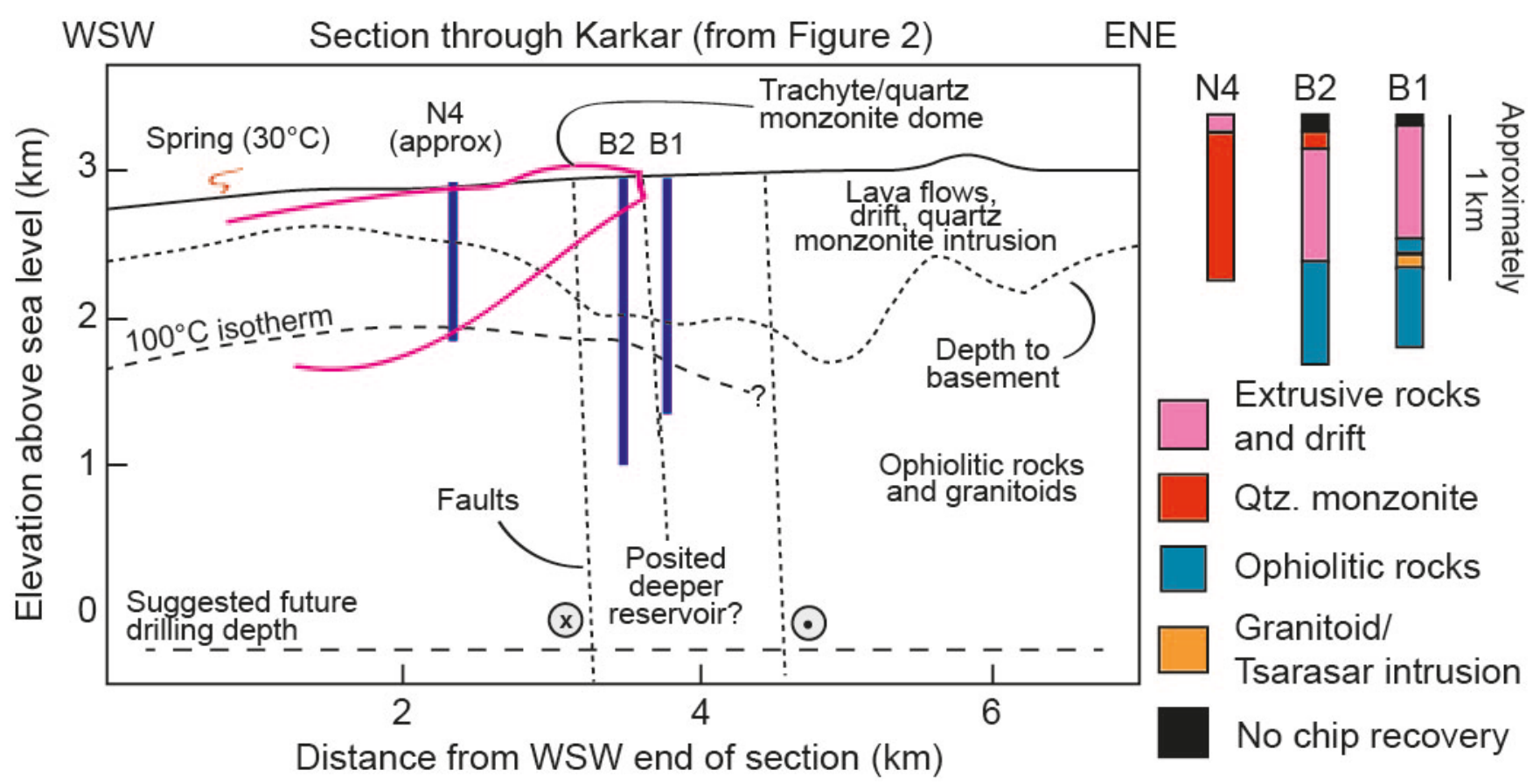

\begin{abstract}
Figure 3. E-W Cross section model and schematic logs for the Karkar monogenetic field at the present day, as summarised and modified from Gilliland et al. (2018).
\end{abstract}

\title{
3. Field observations
}

The recent lavas erupted from fissures with limited morphological expression (Fig. 4a) but demonstrate a clear N-S alignment of fissure sites (Figure 2a). There is a total of 33 individual eruption sites of likely Late Pleistocene to Holocene age. In the south of the field area, fountaining behaviour built up cones of moderately scoriaceous agglomerate transiting to blocks with up to $50 \mathrm{~m}$ prominence (summits of Paytasar and Nazeli; Fig. 4b). Only weakly constrained by existing topography, the lavas have flowed between 1.5 and $8.5 \mathrm{~km}$ from source, the longest and most voluminous emitting from the summit of Paytasar (volume estimated to be $\sim 77 \times 10^{6} \mathrm{~m}^{3}$; based on GIS-based area calculations, field-observed flow thicknesses and digital elevation models). Remote sensing reveals several hundredmetre long ogives intersected by linear cooling cracks, and there are occasional crease structures a few $\mathrm{m}$ deep visible on the ground (Fig. 4c). The lava flows range from weakly vesicular to slightly scoriaceous a'a to blocky type, with the majority of surfaces broken up into large dm- to m-scale blocks. Exposure is insufficient to appreciate more of the feeder system, but it is likely the magmas ascended in dyke-like fashion via existing fault planes or fractures. These formed in relation to the afore-mentioned pull-apart structure between different branches of the PSSF. A total volume estimate based on the above methodology for erupted Holocene lavas at Karkar is $\sim 342$ million $\mathrm{m}^{3}(\sim 0.34$ $\left.\mathrm{km}^{3}\right)$.

We return to the question of the age and origin of the youngest monogenetic volcanic activity around Karkar. Seven lavas from immediately SE of the borehole locations were dated and geochemically analysed for this project, following a walk-over in summer 2016. Brief sample details are reported in Table 1. A single sample collected in 2015 from the most northerly of the Late Pleistocene - Holocene flows has been analysed separately at Oregon State University, providing a Holocene plateau age of $8.3 \pm 1.5 \mathrm{ka}(2 \sigma$, Balasanyan et al., 2017). This age, produced by Koppers and Miggins at the OSU geochronology lab, will be reported in full in a separate publication (Balasanyan et al., 2020, in preparation). 
(a) Facing N from approx N39.718 E46.009

(b) Facing S from approx N39.720 E46.009

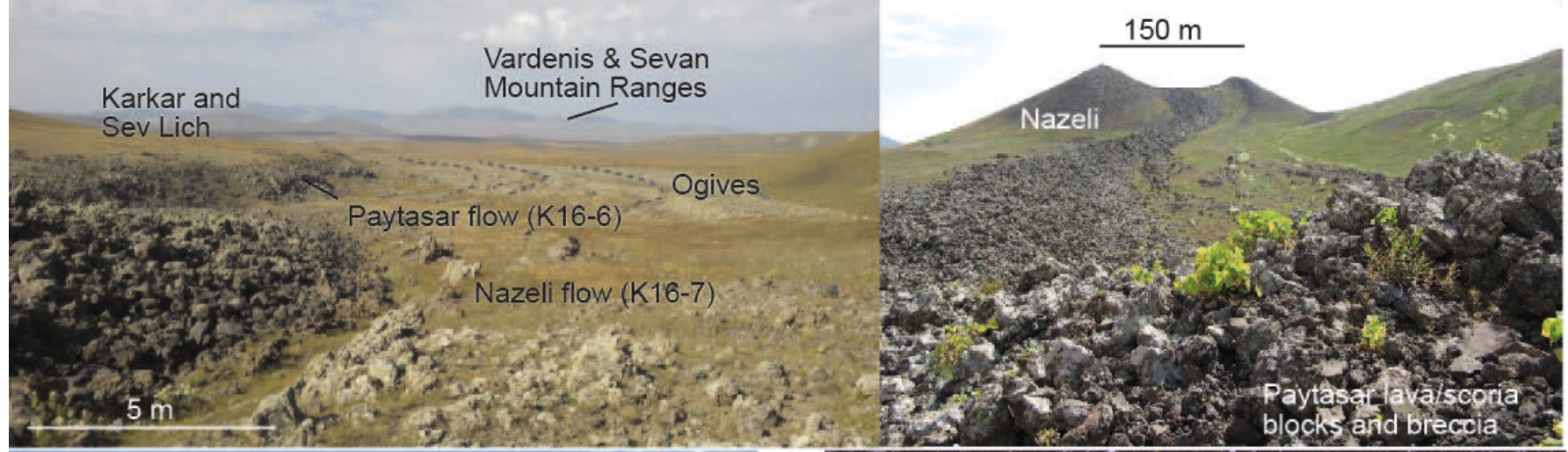

(C) Facing W from approx N39.739 E46.003 (K16-5)
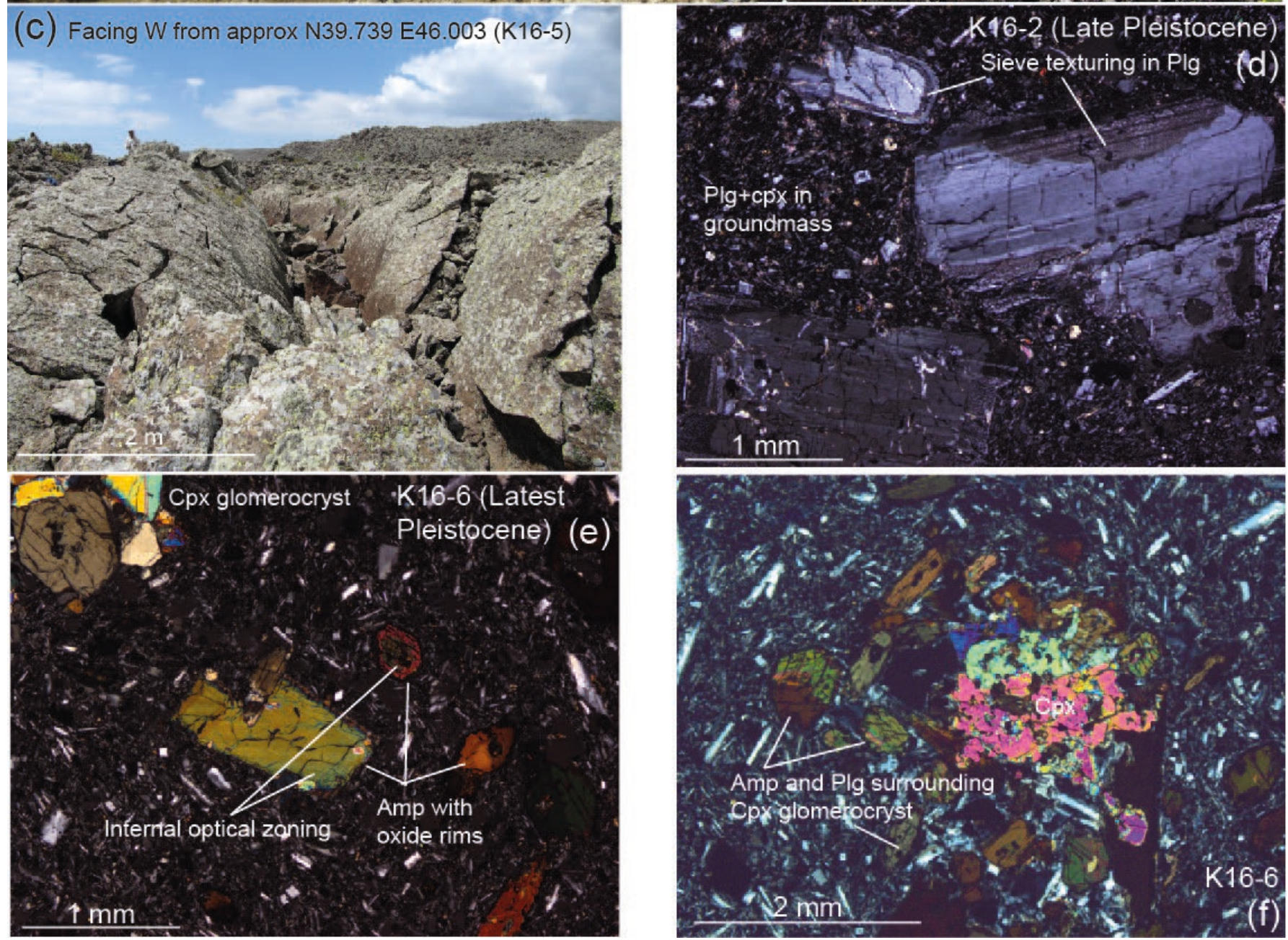

Figure 4. a) Overview of the Karkar field, taken from the middle of the lava flow from Nazeli volcano, showing typical landscapes and lava flows wrinkled into ogives. b) View of the Nazeli volcano (K16-7) showing a scoria cone comprising breccia, blocks and bombs, and the associated lava flow. c) General morphology of the Karkar lava flows, showing a crease structure in flow K16-5. d) Cross-polarised light image of K16-2 (152 $\pm 12 \mathrm{ka})$ showing dominant sieve-textured plagioclase macrocrysts. e) Cross-polarised light image of K16-6 (13 $\pm 4 \mathrm{ka})$ with an amphibole-dominated phenocryst assemblage alongside clinopyroxene glomerocrysts. f) Cross-polarised light image of K16-6 showing clinopyroxene glomerocryst overgrown with amphibole and plagioclase.

Table 1. Summary of petrographic information from the Karkar monogenetic field. The sample details column records sample number, vesicularity (\%), ${ }^{40} \mathrm{Ar}{ }^{39} \mathrm{Ar}$ plateau ages for older Pleistocene lavas, plateau and inverse isochron ages for Late Pleistocene to Holocene lavas, and stages based on the most recent International Commission on Stratigraphy definition (Cohen et al. 2019). Mineralogy is presented in approximate order of occurrence, most common first. 


\begin{tabular}{|c|c|c|c|c|}
\hline Sample details & Co-ordinates & Overall texture & Groundmass & Phenocrysts \\
\hline $\begin{array}{l}\text { K16-1 } \sim 5 \% \\
332 \pm 9 \text { ka plateau } \\
\text { Pleistocene-Middle }\end{array}$ & $\begin{array}{l}\mathrm{N} 39.744854 \\
\mathrm{E} 45.939505\end{array}$ & $\begin{array}{l}90-95 \% \text { groundmass }<0.25 \mathrm{~mm} \\
5-10 \% \text { phenocrysts, rarely } \\
\text { glomerocrysts } 1-2 \mathrm{~mm} \\
\text { rare filled vesicles (calcite) }\end{array}$ & $\begin{array}{l}\text { plagioclase, glass, } \\
\text { oxides, apatite }\end{array}$ & $\begin{array}{lr}\text { clinopyroxene, } & 299 \\
\text { plagioclase, amphibode } & 300 \\
\text { (oxide rims), } & 301 \\
\text { orthopyroxene } & 301\end{array}$ \\
\hline $\begin{array}{l}\text { K16-2 } \sim 2 \% \\
152 \pm 12 \text { ka plateau } \\
\text { Pleistocene-Late } \\
\text { Middle }\end{array}$ & $\begin{array}{l}\text { N39.736224 } \\
\text { E45.950037 }\end{array}$ & $\begin{array}{l}80 \% \text { groundmass }<0.3 \mathrm{~mm} \\
20 \% \text { phenocrysts, some } \\
\text { glomerocrysts } 0.5-4 \mathrm{~mm} \\
\text { rare calcitised patches }\end{array}$ & $\begin{array}{l}\text { plagioclase, } \\
\text { clinopyroxene, } \\
\text { oxides }\end{array}$ & $\begin{array}{l}\text { plagioclase (sieve } 302 \\
\text { textured, concentric } 303 \\
\text { zoning), clinopyroxe3064 } \\
\text { orthopyroxene (rimmed } \\
\text { by clinopyroxene } \\
\text { microlites) }\end{array}$ \\
\hline $\begin{array}{l}\text { K16-3 2-5\% } \\
86 \pm 10 \text { ka plateau } \\
\text { Pleistocene-Early } \\
\text { Late }\end{array}$ & $\begin{array}{l}\text { N39.753230 } \\
\text { E46.017799 }\end{array}$ & $\begin{array}{l}95 \% \text { groundmass }<0.3 \mathrm{~mm} \\
5 \% \text { phenocrysts up to } 5 \mathrm{~mm} \\
\text { hiatal texture }\end{array}$ & $\begin{array}{l}\text { plagioclase, } \\
\text { clinopyroxene, } \\
\text { oxides, glass }\end{array}$ & $\begin{array}{lr}\text { plagioclase (sieve } & 307 \\
\text { textured, faintly zone\$108 } \\
\text { orthopyroxene } & 309\end{array}$ \\
\hline $\begin{array}{l}\text { K16-4 } \sim 10 \% \\
9 \pm 4 \text { ka plateau } \\
\text { Isochron } 8 \pm 3 \mathrm{ka} \\
\text { Holocene- } \\
\text { Greenlandian }\end{array}$ & $\begin{array}{l}\text { N39.741133 } \\
\text { E46.005302 }\end{array}$ & $\begin{array}{l}80 \% \text { groundmass }<0.3 \mathrm{~mm} \\
20 \% \text { phenocrysts, some } \\
\text { glomerocrysts up to } 4 \mathrm{~mm}\end{array}$ & $\begin{array}{l}\text { acicular plagioclase, } \\
\text { oxides, glass }\end{array}$ & $\begin{array}{ll}\text { amphibole (oxide rimsto } \\
\text { plagioclase (sieve } & 311 \\
\text { textured), rare } & 312 \\
\text { clinopyroxene } & 313 \\
& 314\end{array}$ \\
\hline $\begin{array}{l}\text { K16-5 1-2 \% } \\
14 \pm 4 \text { ka plateau } \\
\text { Isochron } 16 \pm 5 \mathrm{ka} \\
\text { Pleistocene- } \\
\text { Tarantian }\end{array}$ & $\begin{array}{l}\text { N39.737838 } \\
\text { E46.000792 }\end{array}$ & $\begin{array}{l}85 \% \text { groundmass } \sim 0.3 \mathrm{~mm} \\
15 \% \text { phenocrysts, some } \\
\text { glomerocrysts up to } 4 \mathrm{~mm}\end{array}$ & $\begin{array}{l}\text { acicular plagioclase, } \\
\text { oxides, glass }\end{array}$ & $\begin{array}{ll}\text { amphibole (oxide rims } & \\
\text { plagioclase (sieve } & 315 \\
\text { textured), rare } & 316 \\
\text { clinopyroxene } & 317 \\
& 318\end{array}$ \\
\hline $\begin{array}{l}\text { K16-6 1-2 \% } \\
13 \pm 4 \text { ka plateau } \\
\text { Isochron } 25 \pm 9 \mathrm{ka} \\
\text { Pleistocene- } \\
\text { Tarantian }\end{array}$ & $\begin{array}{l}\text { N39.721467 } \\
\text { E46.006254 }\end{array}$ & $\begin{array}{l}80 \% \text { groundmass } \sim 0.3 \mathrm{~mm} \\
20 \% \text { phenocrysts, some } \\
\text { glomerocrysts up to } 4 \mathrm{~mm}\end{array}$ & $\begin{array}{l}\text { acicular plagioclase, } \\
\text { oxides, glass, } \\
\text { apatite }\end{array}$ & $\begin{array}{ll}\text { amphibole (oxide rim } 3 \hat{3}, 9 \\
\text { plagioclase (sieve } \\
\text { textured), rare } & 320 \\
\text { clinopyroxene } & 321 \\
& 322 \\
\end{array}$ \\
\hline $\begin{array}{l}\text { K16-7 } \sim 5-10 \% \\
9 \pm 3 \text { ka plateau } \\
\text { Isochron } 6 \pm 3 \mathrm{ka} \\
\text { Greenlandian- } \\
\text { Northgrippian }\end{array}$ & $\begin{array}{l}\text { N39.717234 } \\
\text { E46.008745 }\end{array}$ & $\begin{array}{l}90 \% \text { groundmass up to } 1 \mathrm{~mm} \\
10 \% \text { phenocrysts up to } 3 \mathrm{~mm}\end{array}$ & $\begin{array}{l}\text { acicular plagioclase, } \\
\text { oxides, amphibole, } \\
\text { clinopyroxene, } \\
\text { apatite }\end{array}$ & $\begin{array}{lr}\text { amphibole (oxide rings } 23 \\
\text { plagioclase (sieve } & 324 \\
\text { textured), rare } & 325 \\
\text { clinopyroxene } & 326 \\
& 326\end{array}$ \\
\hline
\end{tabular}

\section{Analytical methods}

Samples for ${ }^{40} \mathrm{Ar} /{ }^{39} \mathrm{Ar}$ geochronology were initially prepared at the Scottish Universities Environmental Research Centre (SUERC) and Glasgow University. Each sample was pulverized by steel jaw crusher, sieved, rinsed in deionized water and dried. The $125-250 \mu \mathrm{m}$ fraction was passed over by hand magnet before electrodynamic separation. Groundmass was carefully hand-picked under a binocular microscope to ensure, as far as possible, that phenocrysts including plagioclase and amphibole were not included in the final samples, each weighing several hundred mg. Samples and neutron flux monitors were packaged in copper foil and stacked in quartz tubes with the relative positions of packets precisely measured for later reconstruction of neutron flux gradients. The sample package was irradiated in the Oregon State University reactor Cd-shielded facility. Alder Creek sanidine (1.1891 \pm $0.0008 \mathrm{Ma}(1 \sigma)$, Niespolo et al. 2017) was used to monitor ${ }^{39} \mathrm{Ar}$ production and establish J values. At SUERC, gas was extracted from samples via step-heating using a mid-infrared $(10.6 \mu \mathrm{m}) \mathrm{CO}_{2}$ laser with a non-gaussian, uniform energy profile and a $3.5 \mathrm{~mm}$ beam diameter rastered over the sample well. The samples were housed in a doubly pumped $\mathrm{ZnS}$-window laser cell and loaded into a copper planchette containing four $2.56 \mathrm{~cm}^{2}$ wells. Liberated argon was purified of active gases, e.g., $\mathrm{CO}_{2}, \mathrm{H}_{2} \mathrm{O}, \mathrm{H}_{2}, \mathrm{~N}_{2}, \mathrm{CH}_{4}$, using three $\mathrm{Zr}$-Al getters; one at $16^{\circ} \mathrm{C}$ and two at $400^{\circ} \mathrm{C}$. Data were collected on a Mass Analyser Products MAP-215-50 single-collector mass spectrometer using an electron multiplier collector in dynamic collection (peak hopping) mode. Time-intensity data were regressed to inlet time with second-order polynomial fits to the data. The average total system blank for laser extractions, measured between each sample run, was $4.8 \pm 0.1 \times 10^{-15} \mathrm{~mol}{ }^{40} \mathrm{Ar}, 12.3 \pm 0.9 \times 10^{-17} \mathrm{~mol}{ }^{39} \mathrm{Ar}$, and $1.9 \pm 0.2 \times 10^{-17} \mathrm{~mol}{ }^{36} \mathrm{Ar}$. Mass discrimination was monitored daily, between and within sample runs, by analysis of an air standard aliquot delivered by an automated pipette. All blank, interference and mass discrimination corrections and age calculations were performed with the MassSpec software package (MassSpec, version 8.058, by Al Deino, Berkeley Geochronology Center). Decay constants are taken from Renne et al. (2011). Each sample was run in duplicate with each single analysis converted into a plateau age such that all included steps overlap in age within $2 \sigma$ uncertainty, have a minimum $n=3$, contain a minimum $50 \%$ of ${ }^{39} \mathrm{Ar}$, and define an inverse isochron indistinguishable from the plateau age at $2 \sigma$ uncertainty. Additionally, the trapped component composition, derived 
from the inverse isochron, is indistinguishable from air at $2 \sigma$. Age and uncertainty were defined by the mean weighted by the inverse variance of each step. The final plateau or isochron age was calculated using only the accepted plateau steps from the duplicate runs. A summary of results is presented in Table 2 and Figure 5, with full details available in Supplementary Items 1 (plateau and inverse isochron images) and 2 (raw and processed data).

Samples for whole rock geochemistry were crushed using a steel jaw crusher at the University of Glasgow and powdered to $<100 \mu \mathrm{m}$ using agate pots in a Retsch Planetary Ball Mill at the University of Cardiff. For major element chemistry, samples were analysed at the University of Edinburgh. Approximately $1 \mathrm{~g}$ of dried sample was ignited to $1100^{\circ} \mathrm{C}$ to calculate loss-on-ignition. A further unignited aliquot was heated with $5: 1$ borate flux in a platinum crucible to $1100^{\circ} \mathrm{C}$ for 20 minutes before cooling to room temperature. The original ratio was made up with fresh flux and the sample recast on a graphite plate. Discs were analysed on a Phillips PW2404 wavelength dispersive sequential $\mathrm{x}$-ray spectrometer alongside a range of international standards for calibration and quality control. Analyses of international standard JB1a ( $\mathrm{n}=3$; Govindaraju, 1994) gave first relative standard deviations of $<4 \%$ for abundant major elements and $<1 \%$ for those present at $\leq 3 \mathrm{wt} . \%$. Trace element solution geochemistry was conducted on an Agilent 7500ce mass spectrometer at the Scottish Universities Environmental Research Centre. Samples were dissolved using a $\mathrm{HF}+\mathrm{HNO}_{3}+\mathrm{HClO}_{4}+\mathrm{HCl}$ digestion procedure to ensure total dissolution of silicates and oxides. First relative standard deviations for all trace elements, were between 0.5 and $3 \%$, notwithstanding $\sim 2 \%$ estimated error in sample weighing and dilution, based on 25 replicate runs of international standard reference material BCR-2.

A small amount of mineral-scale major element data was collected at the University of Manchester School of Earth and Environmental Sciences using a Cameca SX100 Electron Microprobe operating with 5 wavelength dispersive spectrometers at $15 \mathrm{kV}$, with a beam diameter of $5 \mu \mathrm{m}$ and current $15 \mathrm{nA}$ for line and spot analysis. Calibration was carried out using a range of natural and synthetic minerals and oxides, with accuracy tested against secondary standards of augite, hornblende, plagioclase, jadeite and alkali feldspar. The microprobe study gathered two element maps covering around $0.5 \mathrm{~cm}^{2}$ on K16-2 and K16-6, plus point and line scans from plagioclase crystals and more from phenocryst and groundmass clinopyroxene to support the petrographic observations. Financial constraints meant further detailed analysis and geobarometry could not be conducted.

\section{Results}

\subsection{Petrography}

The majority of samples are fresh mafic to intermediate porphyritic, glomerophyric lavas, mostly seriate-textured (Figs 4d-f). Lavas were preferentially sampled for low vesicularity (1-10\%; Table 1) but more vesicular scoria are found in the field, sometimes with white clay or calcite amygdales. The groundmass ranges from hypo- to holocrystalline in texture with $\sim 0.25 \mathrm{~mm}$ grain size, excepting sample K16-7 which has up to $1 \mathrm{~mm}$ grain size. The groundmass is typically hyalopilitic, dominated by weakly-aligned plagioclase feldspar with subordinate clinopyroxene, oxides, apatite \pm amphibole. Phenocrysts and glomerocrysts vary in abundance (5-20\%) and size $(0.5-5 \mathrm{~mm})$. In the youngest samples (K16-4 through 7), amphibole is the dominant phenocryst, with both internal optical zoning and extensive oxide rims (Figs 4e-f). Subordinate plagioclase and clinopyroxene phenocrysts are also present. The older samples (K16-1 through 3) contain varying proportions of plagioclase, clinopyroxene or orthopyroxene phenocrysts and only in K16-1 is a small proportion of amphibole present in the phenocryst assemblage. Plagioclase is often optically zoned, and typically sieve textured (Fig. 4d). Ruby-coloured groundmass iddingsite may be evidence for the former presence of olivine. The glomerocrysts in the older samples typically comprise monomineralic clots of clinopyroxene or plagioclase, or polymineralic clots of these two minerals, clinopyroxene having crystallised earliest. No xenoliths or mafic co-magmatic enclaves, or glomerocrysts larger than a few $\mathrm{mm}$, were found.

Two element maps from K16-2 (Late Pleistocene) and K16-6 (Latest Pleistocene-Holocene) are shown in Figure 5 along with extracted plagioclase anorthite $\mathrm{mol} \%$ and pyroxene $\mathrm{CaO}$ wt.\% concentrations from several transects such as could be gathered in a brief analytical slot. The first plagioclase (Line 1) shows oscillatory zoning in a core of approximately $\mathrm{An}_{43-50}$, similar to the groundmass, with anorthite content generally decreasing towards the rim, before a rapid increase towards higher Ca plagioclase, more anorthite-rich than the groundmass, at the crystal rim $\left(\mathrm{An}_{62-73}\right)$. The second plagioclase transect (Line 2$)$ is through a heavily embayed and sieve-textured crystal, showing anorthite mol \% oscillating around $\mathrm{An}_{20}$, considerably lower than the groundmass plagioclase anorthite concentrations, with no increase in Ca towards the rim. A range of plagioclases included close to the margins of 
analysed clinopyroxene crystals also typically ranged from $\mathrm{An}_{35}-\mathrm{An}_{57}$, in the broad range of the groundmass plagioclases. The mapped clinopyroxene glomerocryst in K16-6 (Figure 5) shows little visual compositional variation or layering, and multiple transects reveal only minor oscillatory zoning with no overall pattern from core to rim.
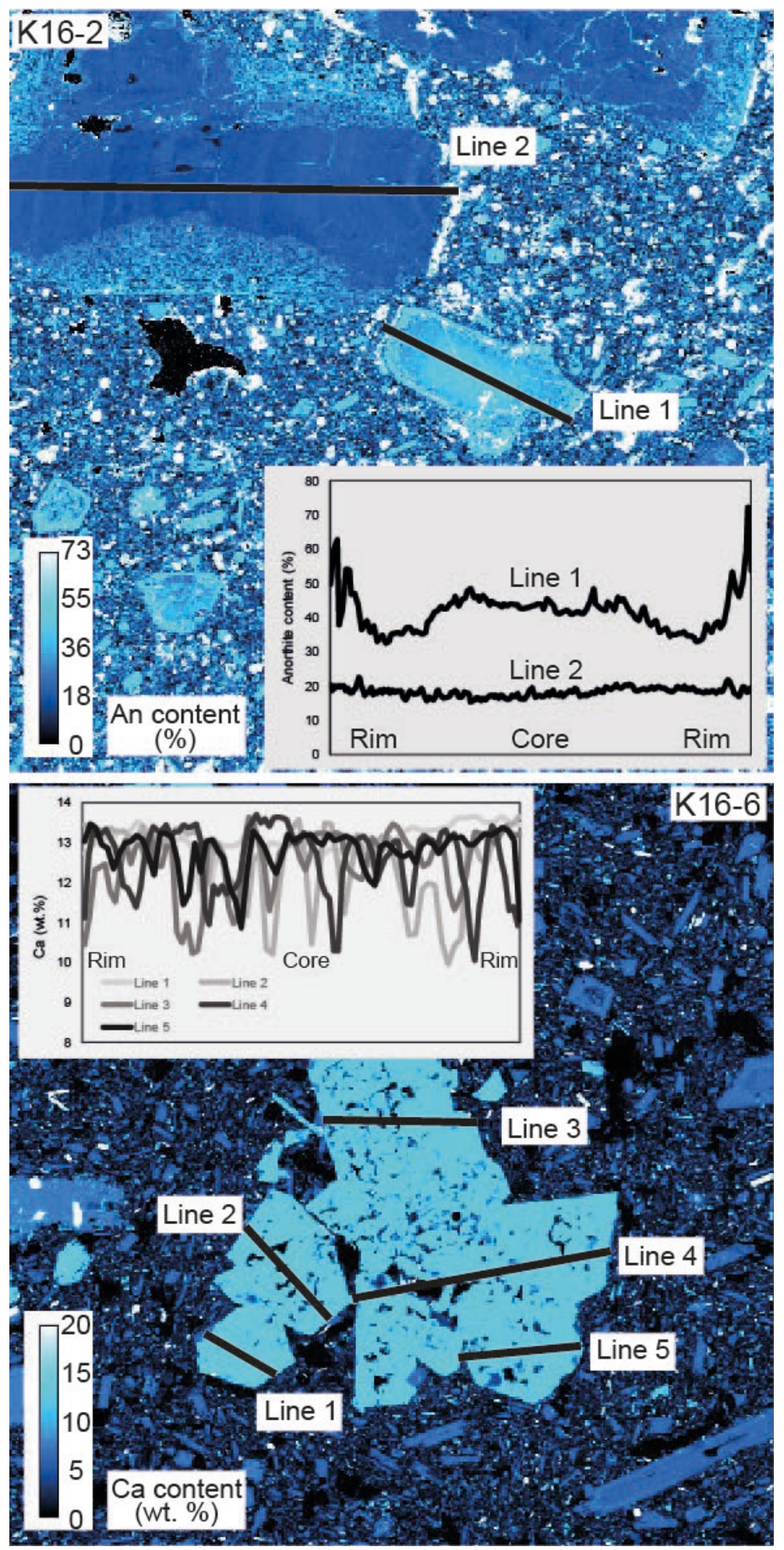

Figure 5. Element maps showing (top) K16-2 (Pleistocene) and (bottom) K16-6 (Holocene). K16-2 shows oscillatory zoning in two large plagioclase crystals, with evident sieve texturing and heterogeneous anorthite concentrations. Line 1 (with inclusions removed) demonstrates late growth of high-Ca plagioclase perhaps indicative of magma mixing, whilst Line 2 may represent an antecryst which shows little internal zonation and 


\subsection{Geochronology}

The seven samples all provided successful duplicate runs from which plateaux could be generated according to the criteria outlined in Section 4 (Table 2). The oldest sampled lava flow from the underlying volcanic units was dated to $332 \pm 9 \mathrm{ka}$ (plateau, K16-1), corresponding to the Middle Pleistocene. Flows immediately underlying the youngest activity have plateau ages of $152 \pm 12$ and $86 \pm 10 \mathrm{ka}$ (K16-2 and K16-3, respectively). The remaining four samples, K16-4 through 7, provided Latest Pleistocene to Holocene ages ranging from K16-5 (plateau $14 \pm 4$ $\mathrm{ka}$, isochron $16 \pm 5 \mathrm{ka}$ ) to K16-7 (plateau $9 \pm 3 \mathrm{ka}$, isochron $6 \pm 3 \mathrm{ka}$ ) (Figure 5). These youngest ages correspond with the stratigraphic relationships between flows as observed in the field. Eruptive centres are clearly visible on satellite imagery and follow an obvious NNW-SSE trend parallel to the strike of the local fault trends (Figure 2a). There is one discrepancy between the stratigraphic order of the older samples and the map developed by the Institute for Geological Sciences. K16-2 is marked on Figure 2b as the first of the Holocene flows, but produced a late Middle Pleistocene plateau age. The location of K16-2 (Figure 2a) also appears to have more pronounced topographic expression and slightly better exposure compared to the subdued topography and poorer exposure of K16-3 (Figure 2a), implying that K16-3 should be the older of the two. However, K16-3 has a significantly younger plateau age dating it to the early Late Pleistocene, a discrepancy which does not appear related to the quality of the samples (Supplementary Item 1). One possible explanation for the greater extent of turf cover on the younger dated sample (K16-3) is that the region of K16-3 has experienced downthrow since $\sim 86$ ka due to fault motion, leaving it prone to ponding of water and greater vegetative cover. The Holocene lavas may also have dammed Sev Lich, resulting in a wetter environment to the east of the younger lavas. The results from K16-7, Greenlandian to Northgrippian of the Holocene, also tally well with ages obtained from flows of the Karkar monogenetic field by cosmogenic ${ }^{3} \mathrm{He}$ dating, of $9.4 \pm 2.4 \mathrm{ka}$ and $5.2 \pm 0.8 \mathrm{ka}(2 \sigma)$. These were reported by Avagyan et al. (2018) in a conference abstract, however the exact locations of these samples were not reported and cannot be directly compared with our study. 

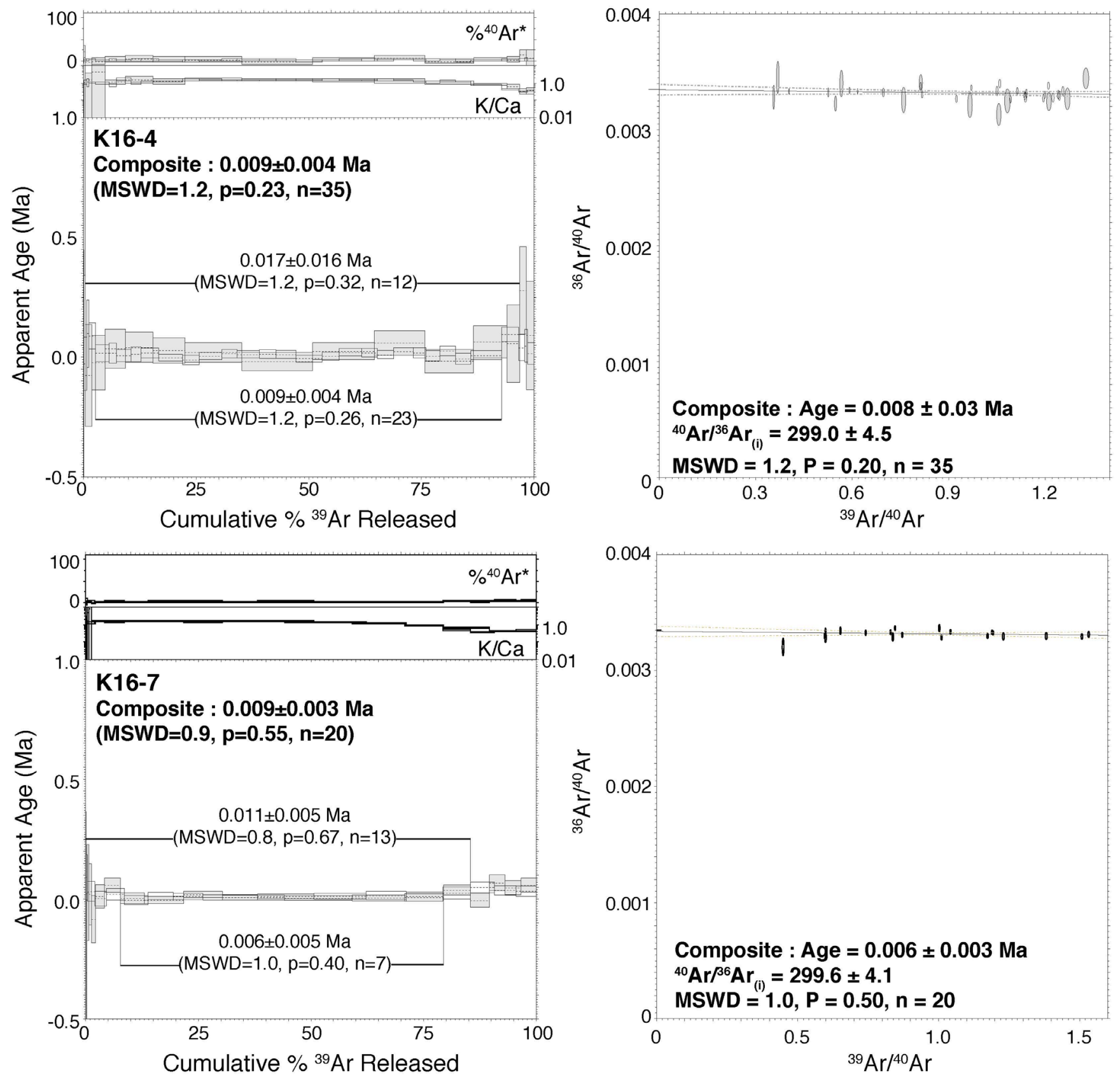

Figure 6. Representative ${ }^{40} \mathrm{Ar} r^{{ }^{9}} \mathrm{Ar}$ age plateau and isochron diagrams for the two apparently youngest samples, K16-4 and K16-7. Full data are presented in the Supplementary Item.

Table 2. Summary of Ar/Ar results for the Karkar monogenetic field. See text for analytical details, Figure 5 for representative plateaux and the Supplementary Item for full data.

\begin{tabular}{|c|c|c|c|c|c|c|c|c|c|c|}
\hline Sample & $\begin{array}{l}\text { Plateau age } \\
\text { (ka) } \pm 2 \sigma \text { incl. } \\
\text { J-value } \\
\text { uncertainty }\end{array}$ & MSWD & $\begin{array}{l}\text { Steps } \\
\text { included }\end{array}$ & $\begin{array}{l}\% \\
\text { total } \\
\text { gas }\end{array}$ & $\begin{array}{l}\text { Mol } \\
{ }^{39} \mathrm{Ar}\end{array}$ & $\begin{array}{l}\text { Plateau } \\
\mathrm{Ca} / \mathrm{K} \pm 2 \sigma\end{array}$ & $\begin{array}{l}\text { Isochron age } \\
\text { (ka) } \pm 2 \sigma \text { incl. } \\
\text { J-value } \\
\text { uncertainty }\end{array}$ & MSWD & $\mathbf{p}$ & ${ }^{40} \mathrm{Ar} /{ }^{36} \mathrm{Ar}_{(\mathrm{i})} \pm 2 \sigma$ \\
\hline K16-1 aliquot 1 & $334 \pm 10$ & 1.2 & $25 / 33$ & 88.1 & $6.2 \mathrm{E}-13$ & $\begin{array}{l}1.01 \pm \\
0.01\end{array}$ & $363 \pm 24$ & 0.9 & 0.53 & $296.5 \pm 1.6$ \\
\hline K16-1 aliquot 2 & $324 \pm 19$ & 1.1 & $18 / 30$ & 71.0 & $2.3 \mathrm{E}-13$ & $\begin{array}{l}0.97 \pm \\
0.02\end{array}$ & $323 \pm 52$ & 1.1 & 0.32 & $298.6 \pm 2.2$ \\
\hline $\begin{array}{l}\text { K16-1 } \\
\text { composite }\end{array}$ & $332 \pm 9$ & 1.1 & $43 / 63$ & & $8.6 \mathrm{E}-13$ & $\begin{array}{l}1.01 \pm \\
0.01\end{array}$ & $353 \pm 20$ & 1.0 & 0.41 & $297.2 \pm 1.2$ \\
\hline K16-2 aliquot 1 & $139 \pm 36$ & 0.8 & $13 / 17$ & 98.0 & $5.8 \mathrm{E}-14$ & $\begin{array}{l}2.29 \pm \\
0.08\end{array}$ & $202 \pm 118$ & 0.9 & 0.59 & $295.6 \pm 14.3$ \\
\hline K16-2 aliquot 2 & $154 \pm 13$ & 0.9 & $36 / 38$ & 93.0 & 7.3E-13 & $\begin{array}{l}2.53 \pm \\
0.03\end{array}$ & $185 \pm 40$ & 0.9 & 0.69 & $297.4 \pm 1.9$ \\
\hline $\begin{array}{l}\text { K16-2 } \\
\text { composite }\end{array}$ & $152 \pm 12$ & 0.9 & $49 / 55$ & & $7.9 \mathrm{E}-13$ & $\begin{array}{l}2.51 \pm \\
0.03\end{array}$ & $177 \pm 36$ & 0.9 & 0.76 & $297.6 \pm 1.8$ \\
\hline
\end{tabular}




\begin{tabular}{|c|c|c|c|c|c|c|c|c|c|c|}
\hline K16-3 aliquot 1 & $70 \pm 30$ & 1.0 & $17 / 17$ & 100.0 & $7.0 \mathrm{E}-14$ & $21.3 \pm 2.1$ & $127 \pm 58$ & 1.0 & 0.47 & $295.2 \pm 7.1$ \\
\hline K16-3 aliquot 2 & $88 \pm 10$ & 1.1 & $25 / 42$ & 75.1 & $6.7 \mathrm{E}-13$ & $\begin{array}{l}0.99 \pm \\
0.01\end{array}$ & $135 \pm 40$ & 1.0 & 0.43 & $295.8 \pm 3.4$ \\
\hline $\begin{array}{l}\text { K16-3 } \\
\text { composite }\end{array}$ & $86 \pm 10$ & 1.1 & $42 / 59$ & & $7.4 \mathrm{E}-13$ & $\begin{array}{l}7.67 \pm \\
0.26\end{array}$ & $135 \pm 33$ & 1.0 & 0.49 & $295.7 \pm 3.0$ \\
\hline K16-4 aliquot 1 & $17 \pm 16$ & 1.2 & $12 / 17$ & 96.4 & $6.4 \mathrm{E}-14$ & $\begin{array}{l}1.02 \pm \\
0.04\end{array}$ & $4 \pm 3$ & 1.2 & 0.27 & $302.9 \pm 14.5$ \\
\hline K16-4 aliquot 2 & $9 \pm 4$ & 1.2 & $23 / 33$ & 90.1 & $8.6 \mathrm{E}-13$ & $\begin{array}{l}0.95 \pm \\
0.01\end{array}$ & $8 \pm 4$ & 1.2 & 0.21 & $298.6 \pm 4.2$ \\
\hline $\begin{array}{l}\text { K16-4 } \\
\text { composite }\end{array}$ & $9 \pm 4$ & 1.2 & $35 / 50$ & & $9.2 \mathrm{E}-13$ & $\begin{array}{l}0.96 \pm \\
0.01\end{array}$ & $8 \pm 3$ & 1.2 & 0.20 & $299.0 \pm 4.5$ \\
\hline K16-5 aliquot 1 & $13 \pm 5$ & 1.1 & $17 / 17$ & 100.0 & 8.9E-13 & $\begin{array}{l}1.70 \pm \\
0.01\end{array}$ & $17 \pm 8$ & 1.1 & 0.32 & $297.5 \pm 3.2$ \\
\hline K16-5 aliquot 2 & $15 \pm 8$ & 1.0 & $11 / 20$ & 95.6 & $7.9 \mathrm{E}-13$ & $\begin{array}{l}1.37 \pm \\
0.01\end{array}$ & $24 \pm 13$ & 1.0 & 0.44 & $297.3 \pm 2.9$ \\
\hline $\begin{array}{l}\text { K16-5 } \\
\text { composite }\end{array}$ & $14 \pm 4$ & 1.0 & $28 / 37$ & & $1.7 \mathrm{E}-12$ & $\begin{array}{l}1.58 \pm \\
0.01\end{array}$ & $16 \pm 5$ & 1.0 & 0.42 & $298.0 \pm 1.8$ \\
\hline K16-6 aliquot 1 & $16 \pm 6$ & 0.7 & $12 / 17$ & 94.7 & $8.1 \mathrm{E}-13$ & $\begin{array}{l}1.49 \pm \\
0.01\end{array}$ & $32 \pm 19$ & 0.6 & 0.83 & $295.0 \pm 6.1$ \\
\hline K16-6 aliquot 2 & $9 \pm 7$ & 0.6 & $14 / 20$ & 97.5 & $8.5 \mathrm{E}-13$ & $\begin{array}{l}1.26 \pm \\
0.01\end{array}$ & $19 \pm 12$ & 0.6 & 0.88 & $297.1 \pm 2.9$ \\
\hline $\begin{array}{l}\text { K16-6 } \\
\text { composite }\end{array}$ & $13 \pm 4$ & 0.7 & $26 / 37$ & & $1.7 \mathrm{E}-12$ & $\begin{array}{l}1.39 \pm \\
0.01\end{array}$ & $25 \pm 9$ & 0.6 & 0.96 & $296.3 \pm 2.3$ \\
\hline K16-7 aliquot 1 & $11 \pm 5$ & 0.8 & $13 / 17$ & 85.4 & $7.6 \mathrm{E}-13$ & $\begin{array}{l}1.22 \pm \\
0.01\end{array}$ & $2 \pm 1$ & 0.7 & 0.75 & $301.8 \pm 5.1$ \\
\hline K16-7 aliquot 2 & $6 \pm 5$ & 1.0 & $7 / 21$ & 71.6 & $6.8 \mathrm{E}-13$ & $\begin{array}{l}0.82 \pm \\
0.01\end{array}$ & $12 \pm 10$ & 1.2 & 0.31 & $296.6 \pm 7.6$ \\
\hline $\begin{array}{l}\text { K16-7 } \\
\text { composite }\end{array}$ & $9 \pm 3$ & 0.9 & $20 / 38$ & & $1.4 \mathrm{E}-12$ & $\begin{array}{l}1.10 \pm \\
0.01\end{array}$ & $6 \pm 3$ & 1.0 & 0.50 & $299.6 \pm 4.1$ \\
\hline
\end{tabular}

5.3. Whole rock geochemistry

The Karkar Group samples are alkaline (Figure 6a) and shoshonitic (Figure 6b) with $\mathrm{K}_{2} \mathrm{O}$ of $\sim 3$ wt.\% and $\mathrm{SiO}_{2}$ ranging from 53 to $58 \mathrm{wt} . \%$ (Table 3). Samples display subtle major- and trace-element differences between the four latest Pleistocene-Holocene (K16-4 through 7) and the three older Pleistocene samples (K16-1 through 3). The oldest samples have evolved trachyandesitic compositions, whereas the youngest samples plot uniformly as less evolved trachybasaltic andesites. All have $\mathrm{MgO}<4$ wt.\%, but the trachyandesites have lower $\mathrm{Al}_{2} \mathrm{O}_{3}, \mathrm{Fe}_{2} \mathrm{O}_{3}, \mathrm{MgO}$, $\mathrm{Na}_{2} \mathrm{O}, \mathrm{TiO}_{2}$ and $\mathrm{P}_{2} \mathrm{O}_{5}$ concentrations and slightly higher $\mathrm{CaO}$ compared with the younger trachybasaltic andesites (Table 3). All samples fall in the 'Syunik' field of collision-related Quaternary volcanism of Sugden et al. (2019), who analysed Pleistocene lavas, scoria and ignimbrites from both mono- and polygenetic centres across Syunik, but not Karkar. The Karkar and Sugden et al. (2019) suites are conspicuous for their high concentrations of $\mathrm{P}_{2} \mathrm{O}_{5}$ compared to Pleistocene samples from elsewhere in Armenia (0.6-1.0 wt.\%).

Chondrite-normalised plots (Figure $6 \mathrm{c}$ ) demonstrate that the older, evolved samples have lower abundances of all REE (rare earth elements) than the younger, less-evolved samples, except for the HREE (heavy REE) Yb and Lu. Both suites have quite flat HREE patterns and very steep, LREE (light REE)-enriched characteristics, with La/Yb $\mathrm{YbN}_{\mathrm{CN}}$ ranging from 24-37, the older samples having the lowest ratios. There are small negative Eu anomalies in each sample, with $\mathrm{Eu} / \mathrm{Eu}^{*}{ }_{\mathrm{CN}}$ ranging from $0.86-0.89$. On a primitive mantle-normalised plot (Figure $6 \mathrm{~d}$ ), samples again mirror others from across Syunik in having negative Nb-Ta anomalies and 'spiky' patterns typical of subductionrelated settings (Sugden et al. 2019). The older, evolved samples have higher Th and K concentrations, but lower $\mathrm{Ba}, \mathrm{Sr}$, and HFSE (high field strength elements, including $\mathrm{Nb}, \mathrm{Ta}, \mathrm{Zr}$ and $\mathrm{Hf}$ ) compared to the younger, less evolved samples. The conspicuous positive Zr-Hf anomaly that has been noted elsewhere in Armenia (Neill et al., 2013) was not picked out here, possibly due to the very incompatible element-enriched nature of the samples. Absolute $\mathrm{Zr}$ ranges from 180-207 ppm, with high $\mathrm{Zr} / \mathrm{Hf}$ ratios of 44-46, matching most other samples with similar $\mathrm{SiO}_{2}$ across Armenia (Sugden et al., 2019). 

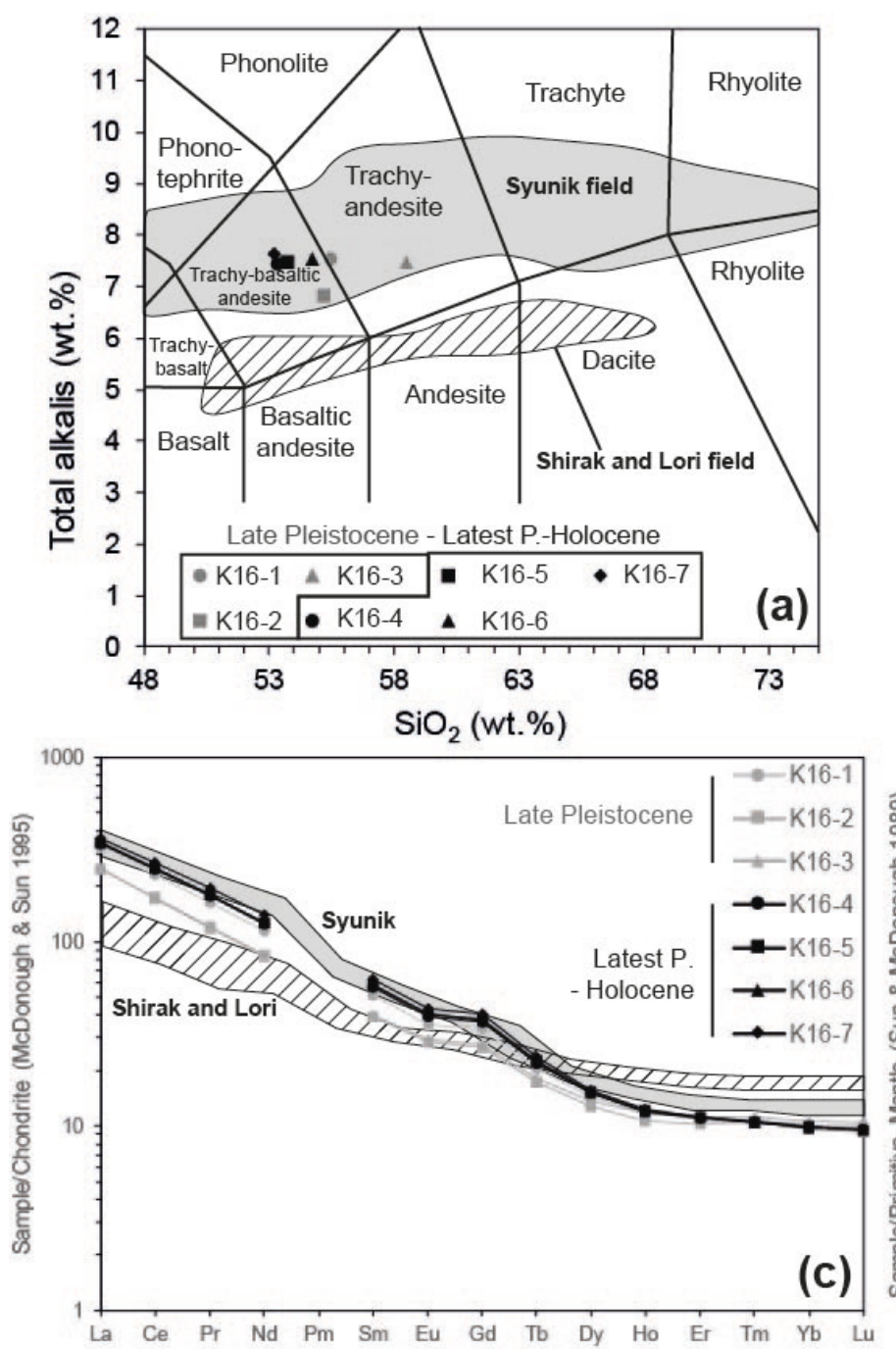
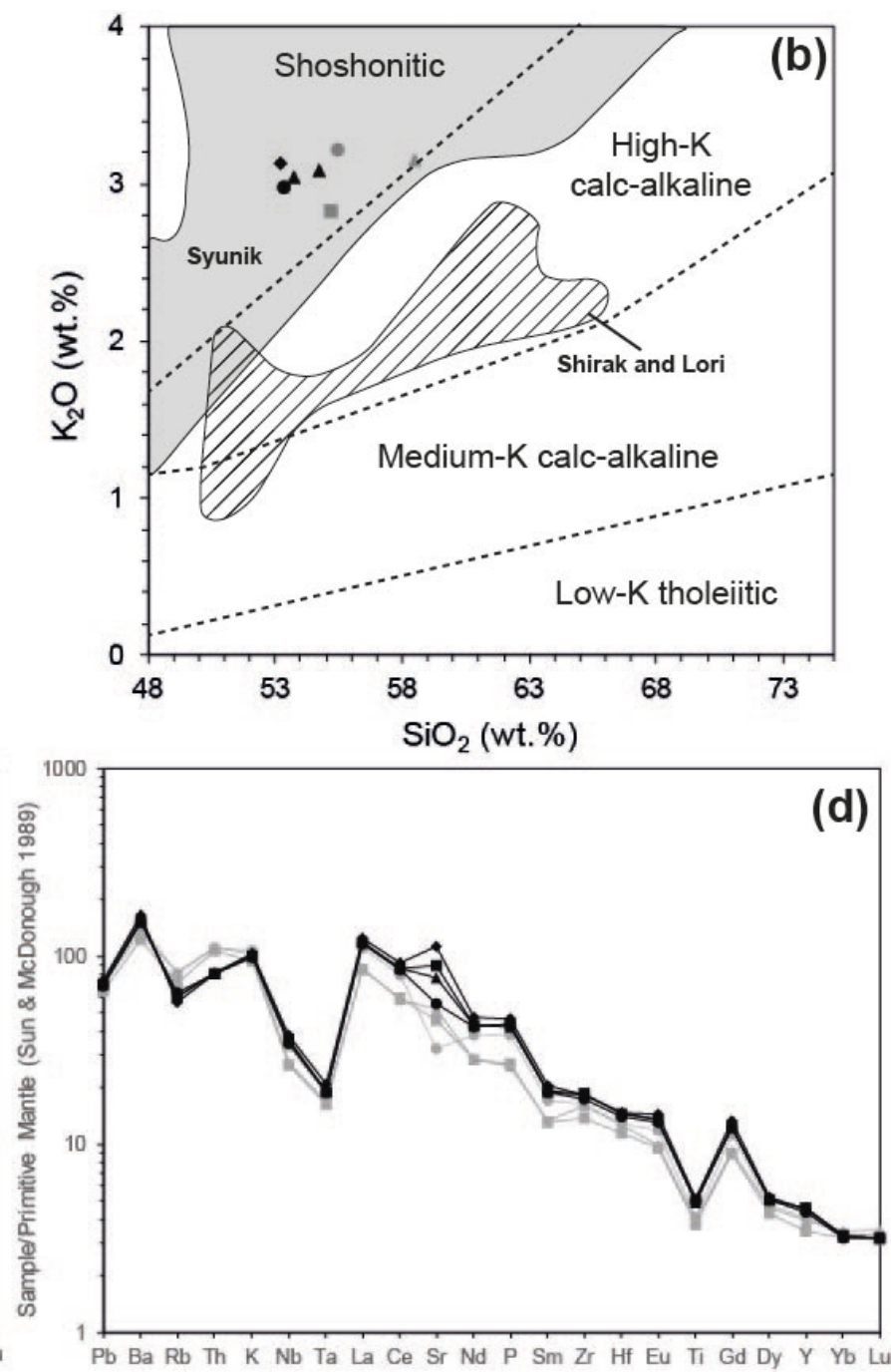

Figure 7. a) Total alkali-silica plot after Le Bas et al. (1986) showing Syunik (southern Armenia) and Shirak/Lori (northern Armenia) fields after Sugden et al. (2019). b) $\mathrm{K}_{2} \mathrm{O}$ vs. silica classification plot after Peccerillo and Taylor (1976). c) Chondrite-normalised plot using normalisation of McDonough and Sun (1995). d) Primitive Mantlenormalised plot using normalisation of Sun and McDonough (1989).

Table 3. Major and trace element geochemistry of samples from the Karkar monogenetic field. Major element oxides are reported in wt.\%, trace elements in parts per million. LOI - loss on ignition. (t) - total iron.

\begin{tabular}{llllllll} 
Sample & K16-1 & K16-2 & K16-3 & K16-4 & K16-5 & K16-6 & K16-7 \\
\hline $\mathrm{SiO}_{2}$ & 55.48 & 55.22 & 58.49 & 53.33 & 53.76 & 54.76 & 53.20 \\
$\mathrm{TiO}_{2}$ & 0.882 & 0.818 & 0.855 & 1.089 & 1.106 & 1.062 & 1.121 \\
$\mathrm{Al}_{2} \mathrm{O}_{3}$ & 16.10 & 15.44 & 16.11 & 16.50 & 16.71 & 16.68 & 16.45 \\
$\mathrm{Fe}_{2} \mathrm{O}_{3}(t)$ & 7.56 & 7.13 & 7.28 & 8.67 & 8.28 & 7.80 & 8.36 \\
$\mathrm{MnO}$ & 0.122 & 0.113 & 0.113 & 0.127 & 0.127 & 0.122 & 0.128 \\
$\mathrm{MgO}$ & 3.47 & 3.25 & 3.18 & 3.64 & 3.67 & 3.52 & 3.88 \\
$\mathrm{CaO}$ & 7.56 & 7.49 & 5.34 & 6.95 & 6.77 & 6.64 & 6.99 \\
$\mathrm{NaO}$ & 4.32 & 4.01 & 4.31 & 4.45 & 4.45 & 4.45 & 4.53 \\
$\mathrm{~K} 2 \mathrm{O}$ & 3.219 & 2.823 & 3.150 & 2.981 & 3.038 & 3.089 & 3.128 \\
$\mathrm{P}_{2} \mathrm{O}_{5}$ & 0.836 & 0.585 & 0.566 & 0.949 & 0.945 & 0.921 & 1.024 \\
$\mathrm{LOI}$ & 0.00 & 2.64 & 0.00 & 0.95 & 0.63 & 0.57 & 0.78 \\
$\mathrm{Total}$ & 99.51 & 99.39 & 99.64 & 99.49 & 99.62 & 99.59 & 99.59 \\
\hline $\mathrm{Sc}$ & 10.2 & 10.1 & 9.9 & 11.4 & 11.7 & 13.1 & 10.6 \\
$\mathrm{~V}$ & 39.6 & 35.0 & 44.0 & 32.2 & 34.6 & 33.7 & 47.9 \\
$\mathrm{Cr}$ & 39.6 & 50.3 & 115.6 & 40.2 & 49.0 & 47.1 & 87.6 \\
$\mathrm{Co}$ & 25.2 & 23.6 & 24.5 & 29.1 & 28.9 & 28.1 & 29.9
\end{tabular}




$\begin{array}{llllllll}\mathrm{Ni} & 61.8 & 104.5 & 134.3 & 121.1 & 191.8 & 161.6 & 21295 \\ \mathrm{Rb} & 51.4 & 45.9 & 52.1 & 40.4 & 38.9 & 38.9 & 36496 \\ \mathrm{Sr} & 679 & 967 & 1110 & 1184 & 1883 & 1616 & 23897 \\ \mathrm{Y} & 18.4 & 15.8 & 18.0 & 20.0 & 21.0 & 20.8 & 20.498 \\ \mathrm{Zr} & 182.8 & 156.0 & 180.3 & 196.2 & 207.5 & 206.1 & 20 \$ 99 \\ \mathrm{Nb} & 23.9 & 18.8 & 19.6 & 24.8 & 26.1 & 25.7 & 27500 \\ \mathrm{Ba} & 1038 & 853 & 844 & 1064 & 1073 & 1103 & 11601 \\ \mathrm{Hf} & 4.0 & 3.5 & 4.0 & 4.3 & 4.5 & 4.6 & 4.5502 \\ \mathrm{Ta} & 0.8 & 0.7 & 0.7 & 0.8 & 0.8 & 0.8 & 0.9503 \\ \mathrm{~Pb} & 13.0 & 12.1 & 13.1 & 12.9 & 13.0 & 13.5 & 13504 \\ \mathrm{Th} & 9.5 & 9.2 & 9.5 & 6.9 & 6.9 & 7.1 & 6.9505 \\ \mathrm{U} & 2.2 & 2.3 & 2.2 & 1.6 & 1.6 & 1.6 & 1.6506 \\ \mathrm{La} & 76.4 & 58.6 & 59.4 & 80.1 & 81.8 & 81.9 & 86507 \\ \mathrm{Ce} & 141.2 & 107.0 & 105.5 & 152.2 & 153.8 & 154.1 & 165.88 \\ \mathrm{Pr} & 15.0 & 11.1 & 11.0 & 16.3 & 16.7 & 16.6 & 18509 \\ \mathrm{Nd} & 52.0 & 38.4 & 38.1 & 57.2 & 58.1 & 58.0 & 64510 \\ \mathrm{Sm} & 7.6 & 5.9 & 5.9 & 8.4 & 8.6 & 8.5 & 9.2511 \\ \mathrm{Eu} & 2.0 & 1.6 & 1.7 & 2.2 & 2.3 & 2.3 & 2.5512 \\ \mathrm{Gd} & 6.7 & 5.3 & 5.5 & 7.3 & 7.5 & 7.4 & 8.0513 \\ \mathrm{~Tb} & 0.7 & 0.6 & 0.7 & 0.8 & 0.8 & 0.8 & 0.9514 \\ \mathrm{Dy} & 3.5 & 3.2 & 3.4 & 3.7 & 3.8 & 3.7 & 3.9515 \\ \mathrm{Ho} & 0.6 & 0.6 & 0.6 & 0.7 & 0.7 & 0.7 & 0.7516 \\ \mathrm{Er} & 1.8 & 1.7 & 1.8 & 1.8 & 1.8 & 1.8 & 1.8517 \\ \mathrm{Tm} & 0.3 & 0.3 & 0.3 & 0.3 & 0.3 & 0.3 & 0.3518 \\ \mathrm{Yb} & 1.6 & 1.6 & 1.7 & 1.6 & 1.6 & 1.6 & 1.6519 \\ \mathrm{Lu} & 0.3 & 0.2 & 0.3 & 0.2 & 0.2 & 0.2 & 0.2520 \\ \mathrm{H} & & & & & & & \end{array}$

\section{Discussion}

\subsection{A Holocene eruption history and recent volcanism associated with the Syunik Fault}

One piece of archaeological evidence has previously been used to justify Holocene magmatism specifically at Karkar (Karakhanian et al., 2002). Blocks of the youngest lava were said to have covered loam associated with obsidian tools, bones and ceramic materials, from which a ${ }^{14} \mathrm{C}$ age of $4720 \pm 140 \mathrm{yr}$ was obtained. No analytical error was mentioned in that paper (Karakhanian et al., 2002). The new inverse isochron ${ }^{40} \mathrm{Ar} /{ }^{39} \mathrm{Ar}$ date for K16-7 (6 $\pm 3 \mathrm{ka}$ ) lies within error of this archaeological age. However, the archaeological age is not within error of the plateau age from this sample, of $9 \pm 3 \mathrm{ka}$. Although we cannot rule out the possibility that the loam sample was contaminated by younger sources of carbon, and therefore might be older than currently recognised, we can also suggest that the plateau age for K16-7 may record a slightly radiogenic trapped Ar component. In that situation we would consider the inverse isochron age of $6 \pm 3 \mathrm{ka}$ to be more acceptable. The youngest of two aforementioned cosmogenic ${ }^{3} \mathrm{He}$ dates, of $5.2 \pm 0.8 \mathrm{ka}$ (Avagyan et al., 2018) also overlaps with the ${ }^{14} \mathrm{C}$ and ${ }^{40} \mathrm{Ar} /{ }^{39} \mathrm{Ar}$ isochron dates. We caution that the true uncertainty of ${ }^{3} \mathrm{He}$ results may be higher than reported, given uncertainties in production scaling and shielding effects, but together the three different methods give confidence that the youngest eruption at Karkar took place only a few thousand years ago. Additionally, the inverse isochron ${ }^{40} \mathrm{Ar} /{ }^{39} \mathrm{Ar}$ date for K16-7 ( $8 \pm 3 \mathrm{ka})$ and the unpublished date from the Oregon lab of $8.3 \pm 1.5 \mathrm{ka}$ for the most northerly of the Karkar flows both lie within $2 \sigma$ error of the older cosmogenic ${ }^{3} \mathrm{He}$ result of $9.4 \pm 2.4$ ka (Avagyan et al., 2018), giving confidence that eruptions took place at three distinct eruption sites a few $\mathrm{km}$ apart during the Holocene at Karkar. We can also add the unpublished result of $3.7 \pm 4.2 \mathrm{ka}(2 \sigma)$ for an eruption at Porak (Meliksetian et al., 2018, discussed below) as evidence of Holocene eruptions having taken place at more than one location along the Syunik Fault. It is therefore necessary to consider the potential for future eruptions in this part of Armenia (see Section 6.4).

Within a few km of Karkar are petroglyphs made in the sleek patina of volcanic blocks, demonstrating that ancient humans were present during the Holocene (Knoll et al., 2013). The carvings, including animals, hunting scenes and human figures, have proven difficult to date beyond qualitative comparison with occurrences elsewhere in the region (Knoll et al., 2013 and discussion in Karakhanian et al. 1997). Between Karkar and Porak volcano (Fig. 1), Karakhanian et al. (2002) described a petroglyph then tentatively ascribed to the $5^{\text {th }}$ millennium $\mathrm{BC}$. The 
petroglyph has been interpreted to depict a strombolian volcanic eruption, characterised by a cone shape, with smaller circular features above and to the right of the cone interpreted as volcanic bombs. If the petroglyph does depict an eruption, then it may represent activity at a nearby volcano, i.e. Porak or the Karkar field. The volcano is presumed to be Porak, on account of its visibility from the petroglyph site (Karakhanian et al., 2002). As mentioned above, Meliksetian et al. (2018) report an ${ }^{40} \mathrm{Ar} /{ }^{39} \mathrm{Ar}$ age of $3.7 \pm 4.2 \mathrm{ka}(2 \sigma)$, but this is for a lava sampled from a flow $\sim 8 \mathrm{~km}$ north of Porak's central cone on a separate fissure. This eruption did not produce fountaining behaviour and would not have been visible from the petroglyph site. Avagyan et al. (2018), however, report a ${ }^{3} \mathrm{He}$ age of $28 \pm$ $12 \mathrm{ka}(2 \sigma)$ for a sample collected from the youngest lava of the main cone of Porak, which would have been formed during strombolian behaviour and would have been visible from the petroglyph site, at odds with the $5^{\text {th }}$ millennium BC age assumption of Karakhanian et al. (2002). If line-of-sight is not considered evidence for the volcano's location, then eruptions of both Paytasar (K16-6, plateau - $13 \pm 4 \mathrm{ka}$, isochron - $25 \pm 9 \mathrm{ka}$ ) and Nazeli (K16-7, isochron - $6 \pm 3 \mathrm{ka}, 2 \sigma$ ) at Karkar both produced strombolian behaviour and could be candidates for the subject of the petroglyph.

Globally, artistic impressions of prehistoric volcanic eruptions are exceptionally rare. A rock painting close to a site where a human footprint is preserved in volcanic ash at Çakallar volcano in western Turkey has recently been dated (Ulusoy et al., 2019). Its $\sim 4.7 \mathrm{ka}$ age is based on ${ }^{36} \mathrm{Cl}$ dating of a lava belonging to the eruption sequence $(4.7 \pm 1.2$ $\mathrm{ka}, 2 \sigma)$ and a combined U-Pb - U-Th/He date from material directly overlying the footprint $(4.7 \pm 1.4 \mathrm{ka}, 2 \sigma)$ (Ulusoy et al., 2019). A cave painting near Çatalhöyük in Central Anatolia is argued to depict the $8.97 \pm 0.64 \mathrm{ka}$ $(2 \sigma)$ eruption of Hasan Dagi volcano around $130 \mathrm{~km}$ away from the site, the eruption being dated by zircon (UTh)/He methods (Schmitt et al., 2014). Another cave painting, near Clermont Ferrand, France, has been dated by ${ }^{14} \mathrm{C}$ methods to between 37 and $34 \mathrm{ka}$ (Quiles et al., 2014). Nomade et al. (2016) used ${ }^{40} \mathrm{Ar} /{ }^{39} \mathrm{Ar}$ dating to corroborate eruption of a nearby volcanic centre between $29 \pm 10 \mathrm{ka}(2 \sigma)$ and $35 \pm 8 \mathrm{ka}(2 \sigma)$. The Armenian petroglyph's true age remains to be determined beyond reasonable doubt, but it is nevertheless one of the oldest known depictions of volcanism.

It is almost certain that inhabitants of the uplands between Lake Sevan and Karkar experienced volcanic activity first-hand. Fountaining behaviour and development of scoria cones would have been visible for many km around and were probably accompanied by moderate earthquakes associated with opening of volcanic fissures. In the example the Great Tolbachik fissure eruption of 1975, these reached magnitudes of $~ 5.5$ (Fedotov et al., 1976; Zobin and Gorelchik, 1982). It is doubtful these events would have been particularly threatening to life, but they may have been locally disruptive and would have formed an intrinsic part of local heritage (Karakhanian et al., 2002).

\subsection{Inferences from petrography}

A range of magmatic processes which will require further research are revealed by the thin section and microprobe work. Glomerocrysts are normally taken as evidence for the dislodging of cumulate piles within the magma conduit or crustal staging chamber(s) prior to or during eruption (e.g. Özdemir et al., 2011; Dungan and Davidson, 2004; Reubi and Blundy, 2008). These are present in all samples of all ages. Amphibole crystals, where present, commonly show oxide rims which are taken to represent breakdown during decompression (Rutherford and Hill, 1993). Sieve texturing in plagioclase, which is ubiquitous, is sometimes also taken as an indicator of disequilibrium due to decompression (Nelson and Montana, 1992), but it is also recognised as a marker for magma mixing (Tepley et al., 1999). Optical zoning in both plagioclase and, where present, amphibole, is consistent with the latter process. In the mapped Late Pleistocene sample (K16-2; Figure 7), the plagioclase represented by Line 1 contains normal zoning in the core, overprinted by a sharp reversal of zoning which indicates mixing with a much less evolved melt prior to eruption. However, the origin of the An-poor, embayed and sieve textured plagioclase shown in Line 2 on Figure 7 is not clearly related to mixing. Disequilibrium with the groundmass and low anorthite content may indicate the crystal was scavenged either as 1) an antecryst from an earlier-formed cumulate pile itself formed from a highly-evolved precursor magma, or 2) a xenocryst from the local crust, which is described above as containing abundant granitoid intrusions. Possible evidence for crustal contamination in the older Late Pleistocene magmas is discussed below. Further detailed quantitative electron microscopy and microprobe work in multiple samples is required to fully discriminate and quantify the importance of these processes.

\subsection{Petrogenesis of the Karkar magmas}

\subsubsection{Are the Late Pleistocene and latest-Pleistocene-Holocene suites genetically related?}


Before addressing the ultimate mantle source of magmatism beneath Karkar, the aforementioned petrographic and geochemical distinctions between the Late Pleistocene ( 332-86 ka) and latest Pleistocene-Holocene ( 14-6 ka) samples is considered. Monogenetic volcanic fields can be strongly compositionally heterogeneous from eruption to eruption, even within individual eruptions (McGee and Smith, 2016). Many factors contribute to heterogeneity, including the tapping of distinct mantle sources or different amounts of mantle melting (Strong and Wolff, 2003; Haase et al., 2004), reactions between rising magmas and mantle wall-rock (Reiners et al., 2002), and whether magmas are extracted directly to the surface or experience storage involving assimilation, fractional crystallisation or magma mixing (e.g., Coote and Shane, 2018). As such, great care has to be taken not to 'assume' a common origin for all Karkar volcanism simply because they erupted in the one location.

Our youngest samples are slightly less evolved than the oldest (53-55 wt.\% vs. 55-58 wt.\% $\mathrm{SiO}_{2}$ ) and there are differences between these two groups in both mineralogy and trace element chemistry: the younger lavas have abundant amphibole phenocrysts, and contain higher concentrations of Al and most incompatible trace elements, particularly $\mathrm{Ba}$ and $\mathrm{Sr}$. However, the older, slightly more evolved samples have higher $\mathrm{Ca}, \mathrm{Rb}, \mathrm{Th}$ and $\mathrm{U}$. When compared on Figure 8a, the youngest samples fall within the Syunik field of Sugden et al. (2019) but the older samples lie slightly above it in the geographically and chemically defined 'Vardenis' field. Figure 8a compares all analysed Quaternary volcanic samples of mafic to felsic composition across Armenia and demonstrates parallel trends for each field which may be generated in each location by FC processes. The vertical differences between locations on Figure 8a are thought to represent different degrees of source enrichment and of partial melting. At Karkar, the older and younger samples do not lie on a tramline-parallel trend and are therefore not clearly related to one another by simple fractional crystallisation. Some of the geochemical variation between samples may be related to amphibole accumulation, which would affect $\mathrm{SiO}_{2}, \mathrm{Al}_{2} \mathrm{O}_{3} \mathrm{CaO}$ and middle REE in the melt. However, the $\mathrm{Dy} / \mathrm{Yb}(\sim 1.5-1.6$ vs. 1.3-1.4) and Dy/Dy* ratios ( 0.52 vs. 0.49$)$ of the younger, amphibole-rich samples are only subtly higher than those of the older, amphibole-free samples (see Davidson et al., 2013 for details). On Figure $8 \mathrm{~b}$ there is instead a trend between all samples which may represent a minor garnet control on HREE systematics. Additionally, a greater proportion of plagioclase fractionation affecting the older lavas could explain their lower Al and $\mathrm{Sr}$ concentrations, although both suites have similar geometric Eu anomalies $\left(\mathrm{Eu} / \mathrm{Eu}^{*}=0.86-0.89\right)$. However, none of amphibole, garnet or plagioclase can be responsible for the other documented differences between the suites: the higher proportions of light REE, $\mathrm{P}, \mathrm{Zr}-\mathrm{Hf}$ and lower $\mathrm{Rb}$ and $\mathrm{Th}$ in the younger samples are not easily explained as none are compatible in these three phases. Therefore, source enrichment or melting processes may be responsible for these variations.

One further possibility is that the older samples may have experienced crustal contamination (Coote and Shane, 2018), which ties in with the occurrence of low-An plagioclase crystals (see Section 6.2 above). Rb and Th are especially abundant in the middle to upper crust and have higher concentrations in the older samples (e.g. 46-52 ppm Rb vs. 36-40 ppm). The lower $\mathrm{Nb}-\mathrm{Ta}$ and $\mathrm{Zr}-\mathrm{Hf}$ in the older more evolved samples may also relate to crustal contamination affecting the older samples, given the middle crust does tend to have lower high field strength element (HFSE) abundances compared to these magmas (Rudnick and Fountain, 1995; Taylor and McLennan, 1985). Though we have no isotopic data to contribute to this debate, it is noted that crustal contamination is considered a rare feature of Quaternary Armenian magmatism (Neill et al., 2015; Sugden et al., 2019). One final possibility to explain differences between older and younger samples is that, as $\mathrm{Rb}$ and $\mathrm{Th}$ are non-conservative elements (e.g., Pearce, 1983), so their abundances may relate to the mantle source composition and in particular the degree of metasomatic enrichment between the Late Pleistocene and the Latest Pleistocene-Holocene. If the mantle source was more heavily metasomatised during generation of the older magmas, then it would be capable of generating high $\mathrm{Rb}$-Th magmas at a slightly higher degree of melting than the more recent ones, resulting in otherwise lower incompatible element concentrations in the older samples. The mantle source would potentially be slightly drier and more refractory by the time of the youngest melting events, causing a lower degree of partial melting, but higher proportions of incompatible elements such as the LREE, P and HFSE and lower abundances of non-conservative $\mathrm{Rb}$ and $\mathrm{Th}$ in the most recent lavas. In this model, low-Ca plagioclase crystals would have to be antecrysts from an earlier but more evolved magma batch. In conclusion, a longer time-span of magmatic activity should be analysed in greater detail in this region, including with radiogenic isotope analyses, to determine if there are genuine systematic changes in partial melting conditions and crustal processing beneath Syunik, in addition to the Armenia-wide work of Sugden et al. (2019). 


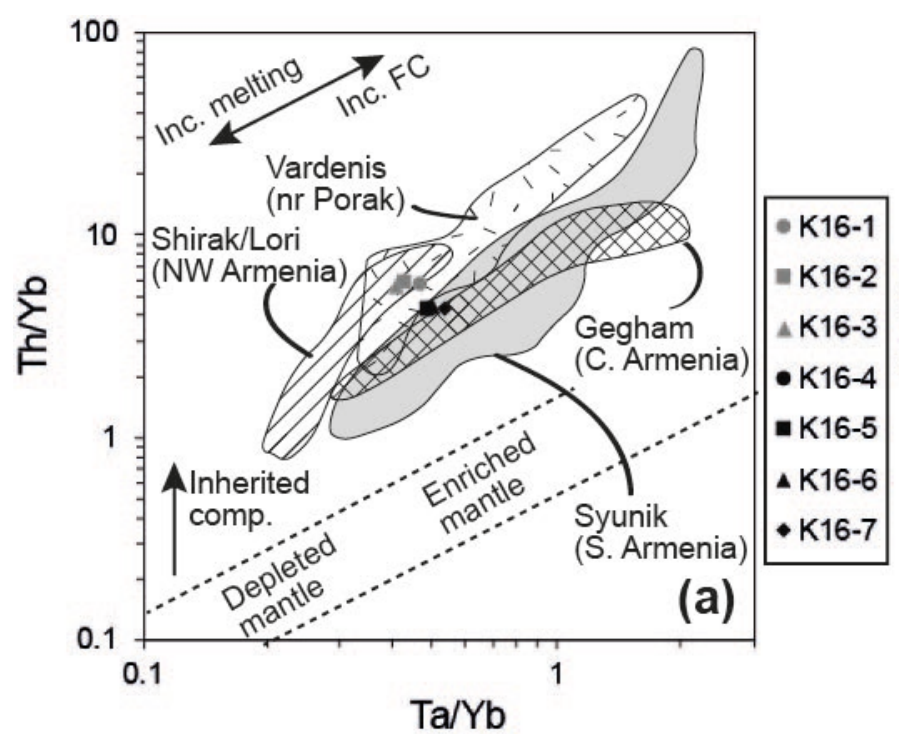

\subsubsection{Depth of melt extraction in relationship to lithospheric thickness}

1.4
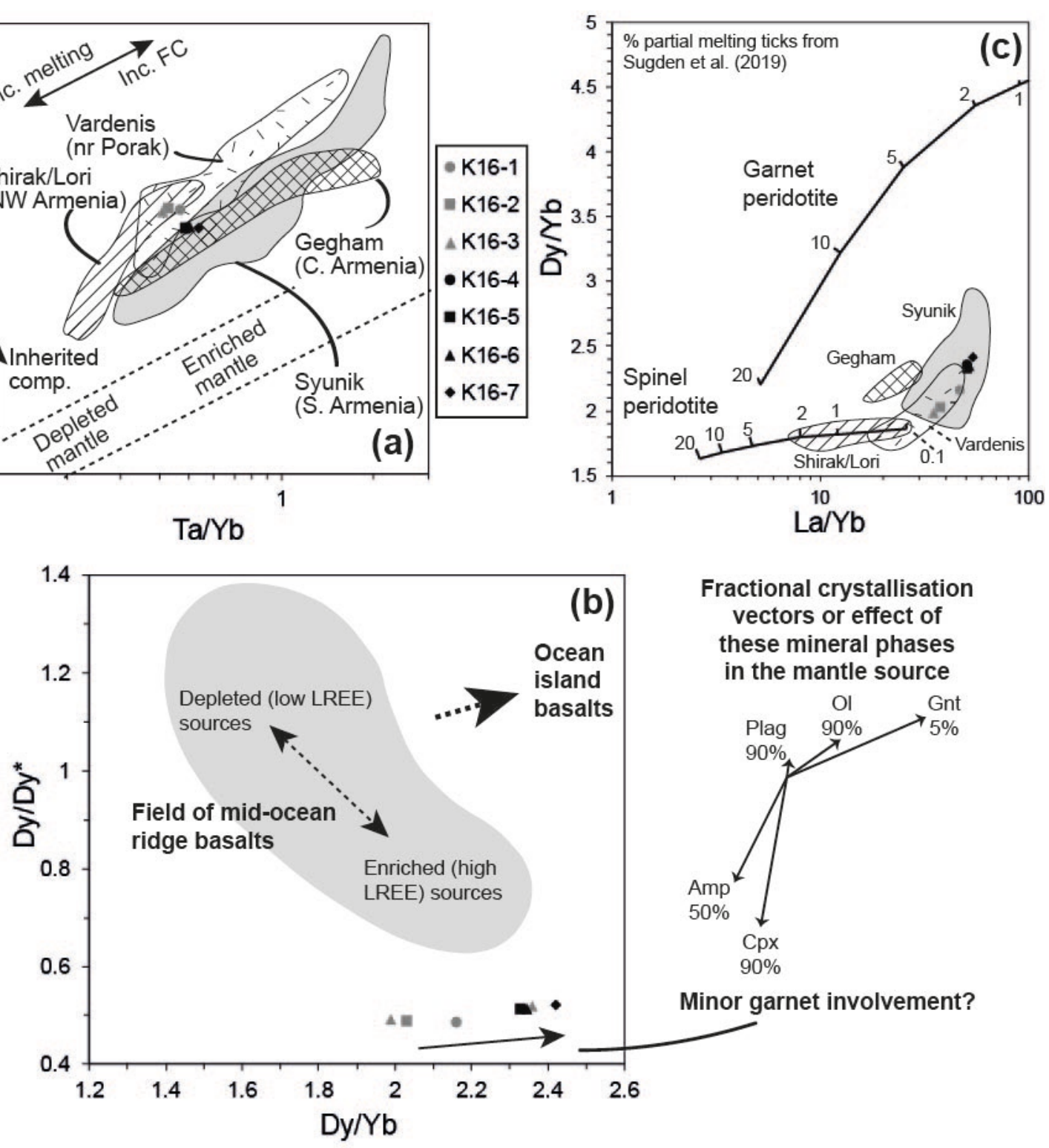

Figure 8. a) Th/Yb vs. Ta/Yb after Pearce (1983) with fields and vectors from Sugden et al. (2019). The youngest Karkar lavas fall clearly within the Syunik field, whereas the older lavas lie just above this field, similar to Vardenis, the location of the Holocene Porak volcano. The FC vector was generated by Sugden et al. (2019) based on fractionation of clinopyroxene, amphibole and plagioclase using modified partition coefficients to account for the change from mafic to more evolved compositions. b) $D y / D y^{*}$ plot with field and vectors derived from Davidson et al. (2013). c) Dy/Yb vs La/Yb plot showing partial melting curves as modelled in Sugden et al. (2019).

The current hypothesis for magma genesis beneath the South Caucasus involves melting of peridotite within the mantle lithosphere (Sugden et al., 2019). Our discussion is framed in the context of Sugden et al.'s dataset and modelling and we have not replicated their work here. Sugden et al. (2019) demonstrated that there is a compositional gradient in mafic Quaternary magmas from N-S in Armenia, characterised by increasing concentrations of fluid-mobile elements and LREE, decreasing concentrations of HREE, and slightly more enriched isotopic signatures (higher ${ }^{87} \mathrm{Sr} /{ }^{86} \mathrm{Sr}$ and lower ${ }^{143} \mathrm{Nd} /{ }^{144} \mathrm{Nd}$ ). Sugden et al. (2019) argued that these changes are a response to increasing lithospheric thickness from N-S in Armenia, resulting in smaller volumes of melting and a colder, but more deeply metasomatised mantle lithosphere towards the $\mathrm{S}$. In the $\mathrm{N}$ of Armenia, where lithospheric thickness is only $\sim 50-60 \mathrm{~km}$, Sugden et al. (2019) modelled up to $3 \%$ non-modal partial melting of spinel peridotite. This lithology would be at the base of the thin lithosphere and melting could be triggered by heating from the convecting asthenosphere. The best-fit model of Sugden et al. (2019) for the mafic lavas of Syunik 
province in southern Armenia instead involved only 1\% melting of a source comprising $65 \%$ garnet peridotite and $35 \%$ spinel peridotite, consistent with the progressively lower HREE abundances towards the S of Armenia (Figure 6c). $4 \%$ apatite was added to the melt mode to explain high magmatic $\mathrm{P}$ concentrations. Because the lithosphere beneath Syunik is $>100 \mathrm{~km}$ thick, this melting in the garnet-spinel transition zone $(\sim 75 \mathrm{~km})$ cannot have taken place at the lithospheric base and may not have been the result of heat transfer from the asthenosphere. Instead, Sugden et al. (2019) proposed a dehydration reaction as the trigger for melting, as subduction-modified lithosphere can cross the amphibole peridotite solidus during collision-related lithospheric thickening. This is an application of a model that is argued to be widely applicable for the generation of mafic melts in active collision zones (Allen et al., 2013).

Predictably given the short eruption timescale, the youngest Karkar samples do not define meaningful evolutionary trends on the total alkali-silica diagram (Fig. 6a) and even the older samples cluster together despite having an age range of $\sim 250 \mathrm{ka}$. The youngest samples are the most mafic ( $\left.\sim 53 \mathrm{wt} . \% \mathrm{SiO}_{2}\right)$, but only contain $3-4 \mathrm{wt} . \% \mathrm{MgO}$. Any primary magma will have fractionated at least olivine, clinopyroxene \pm amphibole \pm plagioclase and would require very imprecise back-projection for petrogenetic calculations. As such, we have not attempted to model the source and partial melting conditions of the Karkar lavas in the style of Sugden et al. (2019). However, the typical 'spiky', light REE-enriched normalised patterns with negative Nb-Ta anomalies (Fig. 6d) are entirely consistent with the proposed source of magmas in the metasomatised mantle lithosphere (Sugden et al., 2019). Flat to slightly steeper heavy REE patterns (Fig. 6c) concur with the Sugden et al. (2019) hypothesis that magmatism in Syunik is derived from very small-volume melting within the garnet-spinel transition zone. This finding is substantiated by a) very low overall abundances of HREE in the Karkar lavas (e.g. $\mathrm{Yb} \leq 1.7 \mathrm{ppm}$ ) implying the presence of some residual garnet, $b$ ) the flat 'garnet' trend on Figure 8b, and c) the Karkar samples lying slightly above the spinel peridotite melting curve of Sugden et al. (2019) in Figure 8c, where partial melts from the garnet-spinel transition zone are expected to plot.

\subsection{Practical consequences of the dating and geochemical information}

\subsubsection{Volcanic hazards, eruption rate and future monitoring}

The temporal recurrence of monogenetic volcanism within the Karkar pull-apart structure is estimated based on ${ }^{40} \mathrm{Ar} /{ }^{39} \mathrm{Ar}$ constraints. Each monogenetic vent is considered as one volcanic episode (Valentine and Connor, 2015). Based on the 33 vents of Late Pleistocene-Holocene age identified by the Institute of Geological Sciences (Fig. 2), and assuming eruption to have occurred within $\sim 332$ to $\sim 6 \mathrm{ka}$, we obtain $9.8 \times 10^{-5}$ events $\mathrm{yr}^{-1}$. The Latest Pleistocene to Holocene interval produced 11 vents across the field, and, if constrained to between $\sim 14$ and $6 \mathrm{ka}$, this yields an order of magnitude higher rate of $9 \times 10^{-4}$ events $\mathrm{yr}^{-1}$; both rates typical of global estimations (Valentine \& Connor, 2015). It is speculated that long-term fluctuation and the apparent clustering of events (e.g. $\sim 14-6 \mathrm{ka}$ ) might relate to tectonic extension in the Karkar pull-apart structure, but a further consideration is the extent to which ice unloading may have assisted the latest Pleistocene-Holocene events (e.g., Sigmundsson et al., 2010). Ollivier et al. (2010) documented numerous moraines associated with ice retreat following the last glaciation in S Armenia, at $\sim 1500 \mathrm{~m}$ above sea level and higher, and much of the South Caucasus uplands were at one time extensively glaciated (Messager et al., 2013). The total number of events at Karkar is towards the low end of the global scale, but comparable with fields of a similar (100-400 ka) age range such as East Eiffel (Germany), Hurricane (United States) and Sabatini (Italy) (compilation in Valentine and Connor, 2015). The areal extent of Karkar, $<100 \mathrm{~km}^{2}$, makes it one of the most geographically limited fields yet identified (McGee and Smith, 2016). Collectively, this picture of temporally clustered, small-volume and low explosivity eruptive activity implies the risk and likely impact on surrounding areas to be generally low.

More generally, many edifices and fissures in Armenia are spatially restricted to fault zones undergoing active extension (Karakhanian et al., 1997; Karakhanyan et al., 2017). This naturally limits where in the country magmatism can occur. The Syunik Fault has among the youngest magmatism which might be expected to continue owing to active extension (Figs 1-2), but much of it has occurred in a remote and currently very sparsely populated on the border between Armenia and Karabagh. The most common eruptive mode is for one or two effusive to weakly pyroclastic events to occur in a volcanic cycle. Lava volumes appear to be small (in the order of $<<0.1 \mathrm{~km}^{3}$ per flow) and most flows only travel a few $\mathrm{km}$. Lava inundation is therefore not a significant hazard, especially at Karkar, but it should nevertheless be considered in natural hazard assessments for any new or existing geothermal infrastructure. None of the Pleistocene to Holocene flows have reached the location of any modern settlements. Greater emphasis might be put on hazard assessment at Porak volcano, given that flows from fissures to the north 
of its cone, including the one dated to the Holocene (Meliksetian et al. 2018), have reached the current locations of at least six villages with a combined population of around 5000. One flow terminates in the outskirts of the regional centre of Vardenis, with a population of $\sim 12,000$. We will discuss Porak as well as Vayots Sar and Smbatassar volcanoes (Fig. 1) in more detail in future communications.

In terms of better quantifying the eruption hazard, a more thorough petrographic review will establish if magma mixing is a viable eruption trigger, over what timescales this occurs (geospeedometry; e.g., Chamberlain et al., 2014), and whether magma mixing might therefore be detectable using geophysical methods as a precursor to future eruptions (e.g. Klügel et al., 2015).

\subsubsection{Possibilities for geothermal exploitation}

In terms of the new geothermal boreholes and the possibility of future exploitation of geothermal energy, the two boreholes at Karkar encountered temperatures sufficient for geothermal power generation (up to $130^{\circ} \mathrm{C}$ ), but with insufficient porosity in the host rocks at shallow depths $(\sim 1 \mathrm{~km})$ (Gilliland et al., 2018). More thorough petrological, geochronological and geophysical techniques may be applied to understand more fully the Karkar system and better exploit the geothermal resource. For example: detailed geothermobarometry would properly constrain recent magma storage depths; seismic monitoring could be a means of determining the location of current magma reservoirs and shallow seismic lines might help determine the 3D structure of the magmatic bodies beneath the surface. We do not know the age or emplacement history of the quartz monzonite, so it is a critical target in establishing whether these intrusive rocks are truly the heat source, or if there is a separate, active, magma chamber or chambers associated with the youngest Holocene volcanism. The aforementioned age results for Porak volcano give reason to consider this volcanic centre also potentially promising for geothermal energy exploration (Meliksetian et al., 2018). As stated by Gilliland et al. (2018), Karkar may be a future site for electricity generation with deeper drilling, but it is distant from larger towns which might benefit from district heating schemes. The nearest villages to Karkar are $>15 \mathrm{~km}$ away (e.g. Sarnakunk), each with fewer than 500 inhabitants, so electricity generation at Karkar would seem the only feasible way forward. In contrast, at Porak, a geothermal development on the heathlands immediately north of Porak summit would be within $10 \mathrm{~km}$ of Vardenis town and various small villages each with populations of a few hundred to over 1000 people, who may benefit both either district heating or from a local electricity source.

\section{Conclusions}

- The Karkar monogenetic field in Syunik Province, SE Armenia, consists of fissure-fed lava flows, sometimes exhibiting weak fountaining behaviour. These were erupted on top of a succession of Late Cenozoic lavas, Oligocene intrusive rocks and Mesozoic ophiolitic materials.

- The youngest volcanic activity at Karkar is associated with a pull-apart structure on the right-lateral Syunik Fault. Ultimately, the magmas were derived by small volume melting of the lithospheric mantle beneath this region, followed by extensive fractional crystallisation. Our ${ }^{40} \mathrm{Ar} /{ }^{39} \mathrm{Ar}$ dating corroborates previous archaeological and unpublished cosmogenic dating that argued for magmatism on the Syunik Fault during the Holocene. Other, unpublished, results from Porak volcano on the same fault imply that this more northerly volcano on the same fault line was also active during the Holocene.

- The work demonstrates that ${ }^{40} \mathrm{Ar} /{ }^{39} \mathrm{Ar}$ dating can be effectively applied to these young rocks, providing the youngest widely accessible peer-reviewed dates from Armenia so far by this method. These results are in spite of a lack of groundmass sanidine which is widely considered the optimum material for analysis. Furthermore, although we took considerable care to avoid any lavas with secondary mineralisation, it is possible that improved results could be obtained by cutting into the dense interior of flows. Further care in sample selection and processing, and perhaps running samples in triplicate, may provide further marginal improvements in precision.

- We caution against the sole use of any dating method, particularly as some may be subject to less quantifiable uncertainties. For example, cosmogenic isotope ages may be affected by a lack of knowledge about winter snow and ice coverage during the Holocene (Delunel et al., 2014). Although some archaeological ${ }^{14} \mathrm{C}$ ages from soil layers have previously been published, these can be very difficult to obtain from beneath thick lava flows owing to very low vegetation levels in these uplands.

- As Karkar is the location of Armenia's first and only geothermal drilling site, further dating is necessary here to fully establish the Pleistocene and older volcanic and intrusive history of the area, and more critical assessment of its long-term eruption rates and probabilistic determination of future eruptions will be of 
benefit. Additional geochemical work is recommended to determine the depth and timing of magma storage and of processes such as magma mixing and crustal contamination. Geophysical and gas monitoring of the Syunik Fault would be an additional measure to corroborate crustal structures and determine if magma is currently being stored in the crust beneath Karkar monogenetic field and the more northerly Porak volcano, which may also be a future geothermal target. Based on past behaviour, Karkar does not appear to pose a significant lava inundation threat to local housing and infrastructure, but Porak may do so.

\section{Acknowledgements}

This paper is dedicated to our much-respected colleague and collaborator Arkady Karakhanian who died suddenly in Yerevan in 2017. The Armenian team and IN were supported by the Armenian State Committee for Science [Grant \# 15T-1E117]. IN was supported by the Carnegie Trust for the Universities of Scotland [Research Incentive Grant 70419, 2016] and the Geological Society of London [Elspeth Matthews Fund, 2016]. EM received an Angus Mitchell Scholarship for MSc research and the Sir Alwyn Williams fund for postgraduate research, both at the University of Glasgow. Bob Gooday conducted sample powdering at Cardiff University. Sponsors had no role in project design, implementation or publishing decisions.

\section{References}

Arutyunyan, E.V., Lebedev, V.A., Chernyshev, I.V., Sagatelyan, A.K. 2007. Geochronology of NeogeneQuaternary volcanism of the Geghama Highland (Lesser Caucasus, Armenia). Doklady Earth Sciences 416, 10421046.

Avagyan A., Ritz J.-F., Blard P.-H., Meliksetian Kh., Munch P., Valla P., Tokhatyan K.S., Mkrtchyan M., Atalyan T. 2018. Volcanic eruptions witnessed by prehistoric people in Armenia. Conference Abstract Volume; Ancient Armenia at the Crossroads, 6-7 Nov. 2018, Lyon, France, p. 15-16.

Baghdasaryan, G.P., Ghukasyan, R.Kh. 1985. Geochronology of magmatic, metamorphic and ore formations of Armenian SSR. Academy of Sciences of the Armenian Soviet Socialist Republic, Yerevan, 291 pp. (in Russian).

Balasanyan, S.V. 2017. The results of study of the tectonic features of the eastern branch of the Syunik pull-apart structure. Proceedings of the National Academy of Sciences of the Republic of Armenia, Earth Sciences 70, 50-58 (in Russian).

Chamberlain, K.J., Morgan, D.J., Wilson, C.J.N. 2014. Timescales of mixing and mobilisation in the Bishop Tuff magma body: perspectives from diffusion chronometry. Contributions to Mineralogy and Petrology 168, Article 1034.

Chernyshev, I.V., Lebedev, V.A., Arakelyants, M.M. 2006. K-Ar dating of Quaternary volcanics: methodology and interpretation of results. Petrology 14, 62-80.

Cohen, K.M., Finney, S.C., Gibbard, P.L., Fan, J.-X. (2019; updated). The ICS International Chronostratigraphic Chart. Episodes 36, 199-204, available at https://stratigraphy.org/index.php/ics-chart-timescale.

Coote, A., Shane, P. 2018. Open-system magmatic behaviour beneath monogenetic volcanoes revealed by the geochemistry, texture and thermobarometry of clinopyroxene, Kaikohe-Bay of Islands volcanic field (New Zealand). Journal of Volcanology and Geothermal Research 368, 51-62.

Davidson, J.P., Turner, S., Plank, T. 2013. Dy/Dy*: Variations arising from mantle sources and petrogenetic processes. Journal of Petrology 54, 525-537.

Delunel, R., Bourles, D.L., van der Beek, P.A., Schlunegger, F., Leya, I., Masarik, J., Paquet, E. 2014. Snow shielding factors for cosmogenic nuclide dating inferred from long-term neutron detector monitoring. Quaternary Geochronology 24, 16-26. 
Dungan, M.A., Davidson, J.P., 2004. Partial assimilative recycling of the mafic plutonic roots of arc volcanoes: an example from the Chilean Andes. Geology 32, 773-776.

Fedotov S., Khrenov, A., Chirkov, A., 1976. The Great Tolbachik Fissure Eruption, Kamchatka, 1975. Doklady Akademii Nauk SSSR V. 228, 5. p. 1193-1196.

Galoyan, G. Rolland, Y., Sosson, M., Corsini, M., Melkonyan, R. 2007. Evidence for superposed MORB, oceanic plateau and volcanic arc series in the Lesser Caucasus (Stepanavan, Armenia). Comptes Rendus Geoscience 339, $482-492$.

GeoRisk, 2012. Independent interpretation of the results of the 3D MT, gravity and $\mathrm{CO}_{2}$ surveys conducted at the Karkar Site. Armenia Geothermal Project Report GEF-CS4-2008 to the Armenian Government, Yerevan, 170 pp.

Gevorgyan, H., Repstock, A., Schulz, B., Meliksetian, Kh., Breitkruez, C., Israyelyan, A. 2018. Decoding a postcollisional multi-stage magma system: The Quaternary ignimbrites of Aragats stratovolcano, western Armenia. Lithos 318, 367-382.

Gilliland, J., Austin, A., Shibesh, K., Wilmarth, M., Daskin, C., Babaya, T. 2018. Karkar, Armenia - Slimehole drilling and testing results and remote project management overview. Proceedings, $7^{\text {th }}$ African Rift Geothermal Conference, Kigali, Rwanda. $31^{\text {st }}$ October $-2^{\text {nd }}$ November 2018.

Govindaraju, K. 1994. Compilation of working values and sample description for 383 geostandards. Geostandandards and Geoanalytical Research 18, 1-158.

Haase, K.M., Goldschmidt, B., Garbe-Schönberg, D. 2004. Petrogenesis of Tertiary continental intra-plate lavas from the Westerwald region, Germany. Journal of Petrology 45, 883-905.

Karakhanian, A., Abgaryan, Y. 2004. Evidence of historical seismicity and volcanism in the Armenian Highland (from Armenian and other sources). Annals of Geophysics 47, 793-810.

Karakhanian, A.S., Trifonov, V.G., Azizbekian, O.G., Hondkarian, D.G., 1997. Relationship of Late Quaternary tectonics and volcanism in the Khanarassar active fault zone, the Armenian Upland. Terra Nova 9, 131-134.

Karakhanian, A., Djrbashian, R., Trifonov, V., Philip, H., Arakelian, S., Avagian, A., 2002. Holocene-historical volcanism and active faults as natural risk factors for Armenia and adjacent countries. Journal of Volcanology and Geothermal Research 113, 319-344.

Karakhanian, A., Trifonov, V.G., Philip, H., Avagyan, A., Hessami, K., Jamali, F., Bayraktutan, M.S., Bagdassarian, H., Arakelian, S., Davtian, V., Adilkhanyan, A., 2004. Active faulting and natural hazards in Armenia, eastern Turkey and northwestern Iran. Tectonophysics 380, 189-219.

Karakhanian, A., Vernant, P, Doerflinger, E., Avagyan, A., Philip, H., Aslanyan, R., Champollion, C., Arakelyan, S., Collard, P., Baghdasarayn, H., Peyret, M, Davtyan, V., Calais, E., Masson, F. 2013. GPS constraints on continental deformation in the Armenian region and Lesser Caucasus. Tectonophysics 592, 39-45.

Karakhanyan, A., Arakelyan, S., Avagyan, A., Sadoyan, T. 2017. Aspects of the seismotectonics of Armenia: new data and re-analysis. In: Sorkhabi, R. (Ed). Tectonic Evolution, Collision, and Seismicity of Southwest Asia: In Honor of Manuel Berberian's Forty Years of Research Contributions. Geological Society of America Special Paper $525,1-32$.

Klügel, A., Longpré, M.-A., García-Cañada, L., Stix, J. 2015. Deep intrusions, lateral magma transport and related uplift at ocean island volcanoes. Earth and Planetary Science Letters 431, 104-149.

Knoll, F., Meller, H., Figur, B., Knoche, G., Schunke, T., Dresely, V., Avetisyan, P., Koiki, T., Lipták, J., Poppe, A. 2013. Die felsbilder im Hochland von Syunik. Veröffentlichungen des Landesamtes für Denkmalpflege und Archäologie Sachsen-Anhalt 67, 209-229. 
Le Bas, M.J., Le Maitre, R.W., Streckeisen, A., Zanettin, B., 1986. A chemical classification of volcanic rocks based on the total alkali-silica diagram. Journal of Petrology 27, 745-750.

Lebedev, V.A., Chernyshev, I.V., Yakushev, A.I. 2011. Initial time and duration of Quaternary magmatism in the Aragats neovolcanic area (Lesser Caucasus, Armenia). Doklady Earth Sciences 437, 532-536.

McDonough, W.F., Sun, S.-S., 1995. The composition of the Earth. Chemical Geology 120, 223-253.

McGee, L.E., Smith, I.E.M. 2016. Interpreting chemical compositions of small-scale basaltic systems: A review. Journal of Volcanology and Geothermal Research 325, 45-60.

Mederer, J., Moritz, R., Ulianov, A., Chiaradia, M., 2013. Middle Jurassic to Cenozoic evolution of arc magmatism during Neotethys subduction and arc-continent collision in the Kapan Zone, southern Armenia. Lithos 177, 61-78.

Meliksetian, Kh., 2013. Pliocene-Quaternary volcanism of the Syunik upland. Veröffentlichungen des Landesamtes für Denkmalpflege und Archäologie Sachsen-Anhalt 67, 247-258.

Meliksetian, Kh., Karakhanyan, A., Badalyan, R., Neill, I., Avagyan, A., Harutyunyan, A., Makaryan, Kh., Balasanyan, S., Navasardyan, G., Miggins, D., Koppers, A. 2018. Conference Abstract Volume; Ancient Armenia at the Crossroads, 6-7 Nov. 2018, Lyon, France, p. 12-14.

Meliksetian, Kh., Lavrushin, V., Shahinyan, H., Aidarkozhina, A., Navasardyan, G., Ermakov, A., Zakaryan, S., Prasolov, E., Maucharyan, D., Gyulnazaryan, S., Grigoryan, E. 2017. Relation of compositions of deep fluids in geothermal activity of Pleistocene-Holocene volcanic fields of Lesser Caucasus. Geophysical Research Abstracts 19, EGU2017-9674.

Melkonyan, R.L., Chung, S.-L., Galoyan, Gh.L., Ghukasyan, R.Kh., Moritz, R., Hovakimyan, S., Atayan, L.S. 2019. New evidence on the U-Pb age estimation for the intrusive complexes of the Tsahkounk-Zanghezour terrain (RA) and some inferences. Proceedings of the National Academy of Sciences of the Republic of Armenia, Earth Sciences 72, 28-36 (in Russian).

Messager, E., Belmecheri, S., von Grafenstein, U., Nomade, S., Ollivier, V., Voinchet, P., Puaud, S., CourtinNomade, A., Guillou, H., Mgeladze, A., Dumoulin, J.-P., Mazuy, A., Lordkipanidze, D. 2013. Late Quaternary record of the vegetation and catchment-related changes from Lake Paravani (Javakheti, South Caucasus). Quaternary Science Reviews 77, 125-140.

Neill, I., Meliksetian, Kh., Allen, M.B., Navasardyan, G., Karapetyan, S., 2013. Pliocene-Quaternary volcanic rocks of NW Armenia: Magmatism and lithospheric dynamics within an active orogenic plateau. Lithos 180-181, 200-215.

Neill, I., Meliksetian, Kh., Allen, M.B., Navasardyan, G., Kuiper, K., 2015. Petrogenesis of mafic collision zone magmatism: the Armenian sector of the Turkish-Iranian plateau. Chemical Geology 403, 24-41.

Nelson, S.T., Montana, A. 1992. Sieve-textured plagioclase in volcanic rocks produced by rapid decompression. American Mineralogist 77, 1242-1249.

Niespolo EM, Rutte D, Deino AL, Renne PR, 2017. Intercalibration and age of the Alder Creek sanidine Ar-40/Ar39 standard. Quaternary Geochronology 39, 205-213.

Nomade, S., Scao, V., Guillou, H., Messager, E., Mgeladze, A., Voichet, P., Renne, P.R., Courtin-Nomade, A., Bardintzeff, J.M., Ferring, R., Lordkipanidze, D. 2016. New ${ }^{40} \mathrm{Ar} /{ }^{39} \mathrm{Ar}$, unspiked K/Ar and geochemical constraints on the Pleistocene magmatism of the Samtskhe-Javakheti highlands (Republic of Georgia). Quaternary International 395, 45-59.

Ollivier, V., Nahapetyan, S., Roiron, P., Gabrielyan, I., Gasparyan, B., Chataigner, C., Joannin, S., Cornée, J.-J., Guillou, H., Scaillet, S., Munch, P., Krijgsman, W., 2010. Quaternary volcano-lacustrine patterns and palaeobotanical data in southern Armenia. Quaternary International 223, 312-326. 
Özdemir, Y., Blundy, J., Güleç, N., 2011. The importance of fractional crystallization and magma mixing in controlling chemical differentiation at Süphan stratovolcano, eastern Anatolia, Turkey. Contributions to Mineralogy and Petrology 162, 573-597.

Pearce, J.A. (1983). Role of sub-continental lithosphere in magma genesis at active continental margins. In: Hawkesworth, C.J., Norry, M.J. (Eds) Continental Basalts and Mantle Xenoliths, Shiva Publishing, Natwich, 230249.

Peccerillo, R., Taylor, S.R., 1976. Geochemistry of Eocene calc-alkaline volcanic rocks from the Kastamonu area, northern Turkey. Contributions to Mineralogy and Petrology 58, 63-81.

Reiners, P.W. 2002. Temporal-compositional trends in intraplate basalt eruptions: Implications for mantle heterogeneity and melting processes. Geochemistry, Geophysics, Geosystems 3, 1-30.

Renne, P.R., Balco G., Ludwig K.R., Mundil, R., Min, K., 2011. Response to the comment by W.H. Schwarz et al. on 'Joint determination of K-40 decay constants and the Ar- $40 * / \mathrm{K}-40$ for the Fish Canyon sanidine standard, and improved accuracy for Ar-40/Ar-39 geochronology" by Renne, P.R., et al., 2010. Geochimica et Cosmochimica Acta $17,5097 \mathrm{e} 5100$.

Reubi, O., Blundy, J., 2008. Assimilation of plutonic roots, formation of high-K 'exotic' melt inclusions and genesis of andesitic magmas at Volcán De Colima, Mexico. Journal of Petrology 49, 2221-2243.

Rolland, Y. 2017. Caucasus collisional history: Review of data from East Anatolia to West Iran. Gondwana Research 49, 130-146.

Ryan, W.B.F., Carbotte, S.M., Coplan, J.O., O’Hara, S., Melkonian, A., Arko, R., Weissel, R.A., Ferrini, V., Goodwillie, A., Nitsche, F., Bonczkowski, J., Zemsky, R. 2009. Global multi-resolution topography synthesis. Geochemistry, Geophysics Geosystems 10, Q03014, doi:10.1029/2008GC002332.

Rudnick, R.L., Fountain, D.M. 1995. Nature and Composition of the Continental Crust: A Lower Crustal Perspective. Reviews of Geophysics 33, 267-309.

Rutherford, M.J., Hill, P.M. 1993. Magma ascent rates from amphibole breakdown: An experimental study applied to the 1980-1986 Mount St. Helens eruptions. Journal of Geophysical Research Solid Earth 98, 19667-19685.

Sahakyan, L., Bosch, D., Sosson, M., Avagyan, A., Galoyan, Gh., Rolland, Y., Bruguier, O., Stepanyan, Zh., Galland, B., Vardanyan, S. 2016. Geochemistry of the Eocene magmatic rocks from the Lesser Caucasus area (Armenia): evidence of a subduction geodynamic environment. In: Sosson, M., Stephenson, R.A., Adamia, S.A. (Eds.). Tectonic evolution of the eastern Black Sea and Caucasus. Geological Society of London Special Publication 428, 73-98.

Sargsyan, L., Meliksetian, Kh., Metaxian, J.-P., Levonyan, A., Karakhanyan, A., Demirchyan, H., Navasardyan, G., Margaryan, S., Gevorgyan, M., Babayan, H. 2017. Preliminary results of the analysis of earthquake swarms in Gegham volcanic ridge (Armenia). Geophysical Research Abstracts 20, EGU2018-417.

Sigmundsson, F., Pinel, V., Lund, B., Albino, F., Pagli, C., Geirsson, H., Sturkell, E. 2010. Climate effects on volcanism: influence on magmatic systems of loading and unloading from ice mass variations, with examples from Iceland. Philosophical Transactions of the Royal Society A 368, doi:10.1098/rsta.2010.0042.

Sosson, M., Rolland, Y., Müller, C., Danelian, T., Melkonyan, R., Kekelia, S., Adamia, A., Babazadeh, V., Kangarli, T., Avagyan, A., Galoyan, G., Mosar, J., 2010. Subductions, obduction and collision in the Lesser Caucasus (Armenia, Azerbaijan, Georgia), new insights. In: Sosson, M., Kaymakci, N., Stephenson, R.A., Bergerat, F., Starostenko, V. (Eds.). Sedimentary Basin Tectonics from the Black Sea and Caucasus to the Arabian Platform. Geological Society of London Special Publication 340, 329-352.

Strong, M., Wolff, J. 2003. Compositional variations within scoria cones. Geology 31, 134-146. 
Sugden, P.J., Savov, I.P., Wilson, M., Meliksetian, K., Navasardyan, G., Halama, R. 2019. The thickness of the mantle lithosphere and collision-related volcanism in the Lesser Caucasus. Journal of Petrology 60, 199-230.

Sun, S.-S., McDonough, W.F., 1989. Chemical and isotopic systematics of oceanic basalts: implications for mantle composition and processes. In: Saunders, A.D., Norry, M.J. (Eds.) Magmatism in the Ocean Basins. Geological Society of London Special Publication 42, 313-345.

Taylor, S.R., McLennan, S.M. 1985. The Continental Crust, Its Composition and Evolution. Blackwell, Cambridge Mass., 312 pp.

Tepley, F.J., III, Davidson, J.P., Clynne, M.A. 1999. Magmatic interactions as recording in plagioclase phenocrysts of Chaos Crags, Lassen Volcanic Centre, California. Journal of Petrology 40, 787-806.

Valentine, G.A., Connor, C.B. 2015. Basaltic Volcanic Fields. In: Sigurdsson, H. The Encyclopaedia of Volcanoes, $2^{\text {nd }}$ Edition, Elsevier Academic Press, pp 423-438.

White, J.T., Karakhanian, A., Connor, C.B., Connor, L., Hughes, J.D., Malservisi, R., Wetmore, P. 2015. Coupling geophysical investigation with hydrothermal modelling to constrain the enthalpy classification of a potential geothermal resource. Journal of Volcanology and Geothermal Research 298, 59-70.

Zobin, V.M., Gorelchik, V.I. 1982. Seismicity and source parameters of earthquakes in the region of the large 